\title{
A 100-Year Review: Fat feeding of dairy cows ${ }^{1}$
}

\author{
D. L. Palmquist*2 and T. C. Jenkins $†$ \\ ${ }^{*}$ Ohio Agricultural Research and Development Center, The Ohio State University, Wooster 44691 \\ †Department of Animal and Veterinary Sciences, Clemson University, Clemson, SC 29634
}

\begin{abstract}
Over 100 years, the Journal of Dairy Science has recorded incredible changes in the utilization of fat for dairy cattle. Fat has progressed from nothing more than a contaminant in some protein supplements to a valuable high-energy substitute for cereal grains, a valuable energy source in its own right, and a modifier of cellular metabolism that is under active investigation in the 21st century. Milestones in the use of fats for dairy cattle from 1917 to 2017 result from the combined efforts of noted scientists and industry personnel worldwide, with much of the research published in Journal of Dairy Science. We are humbled to have been asked to contribute to this historical collection of significant developments in fat research over the past 100 years. Our goal is not to detail all the work published as each development moved forward; rather, it is to point out when publication marked a significant change in thinking regarding use of fat supplements. This approach forced omission of critically important names and publications in many journals as ideas moved forward. However, we hope that a description of the major changes in fat feeding during the past 100 years will stimulate reflection on progress in fat research and encourage further perusal of details of significant events.
\end{abstract}

Key words: fat, conjugated linoleic acid, energy, 100year review

\section{HUMBLE BEGINNINGS-FATS ARE AN AFTERTHOUGHT}

Concepts of feeding fat to dairy cows precede the limits of the past century. Research on feeding oilseeds commenced early; Wood (1894) reported effects of feeding oils from cottonseed, palm, and coconut, as well as oleo oil, corn gluten meal and stearin, concluding that

Received March 23, 2017.

Accepted June 21, 2017.

${ }^{1}$ This review is part of a special issue of the Journal of Dairy Science commissioned to celebrate 100 years of publishing (1917-2017).

${ }^{2}$ Corresponding author: palmquist.1@osu.edu the first effect of feeding oils was to increase milk fat percent. Reports on feeding oils and seeds are found throughout the literature from that time (Henry and Morrison, 1916, "Feeds and Feeding").

Reid (1956) succinctly summarized previous knowledge in his Journal of Dairy Science review of the first 50 years of the American Dairy Science Association as follows:

"After publication of Jordan's reports in 1897 and 1901 that milk fat can be produced from carbohydrates, the viewpoint developed that fat is merely a source of energy exchangeable on an isodynamic basis with other nutrients. As a consequence, for some years thereafter very little attention was given to the fat content of the rations of cows. However, in Germany, Fingerling and his associates between 1904 and 1907 published data which, though showing that sheep and goats can make milk fat from carbohydrates, suggested that fat itself is more efficiently used than is carbohydrate. They also indicated that within certain limits the percentage of fat in milk is influenced by the amount of fat in the ration. These results provoked extensive studies with cows at ten experiment stations in Germany, which were reported by Kellner in 1907. However, since the low-fat rations used provided almost as much fat as was produced in the milk, these experiments provided very inconclusive information."

In the first decade of papers published in Journal of Dairy Science, very few addressed the topic of feeding fat (Appendix Table A1). Discussion of oils began inadvertently in early issues in studies that focused on how protein meals altered milk fat content, eventually raising questions about the possible role of their contaminating oils on observed responses. Palmer and Crockett (1917) reported that feeding cottonseed meal to cows increased melting point and long-chain fatty acids of milk fat, and caused an oily flavor of the milk that could be reversed by feeding corn silage but not hay. McCandlish (1921) continued work on cottonseed meal and milk fat percentage, but rejected reports that 
the amount of oil or fat in a ration affects milk fat percentage stating, "that there is no direct evidence it will do so" - a statement that was eventually proven to be profoundly wrong. Later studies by Woodward (1923) compared feeding linseed oil versus linseed oil meal and concluded that the principal factor causing an increase in milk fat test was the oil rather than the meal. Other studies were concerned mainly with the effect of short-term $(1-3 \mathrm{~d})$ feeding of fat on the official tests for milk fat (Nevins et al., 1926). However, these studies were of short duration, involved few cows, lacked proper experimental design, and used poorly described diets, thus proscribing any conclusions as to usefulness of supplementing fats for milk production.

\section{EFFECTS OF FATS ON LACTATION ARE EXPLORED}

From 1929 until 1943, Maynard and coworkers at Cornell University studied the importance of fat in the ration of dairy cattle (Maynard et al., 1941; Loosli et al., 1944). They found that when an isodynamic amount of fat is replaced by starch, milk yield declines. Although the effect was not great, slightly more milk was produced by cows consuming concentrate mixtures containing 5 to $7 \%$ ether extract than by those consuming concentrates containing from 0.7 to $4 \%$. In the first edition of his classic textbook Animal Nutrition, Maynard (1937) concluded that milk production of cows fed less fat than was produced in the milk yielded less milk. When additions of fat as corn oil, soybean oil, or fatty acids were made to low-fat rations, milk yield did not respond, suggesting that the value of the fat is depressed by extraction from the seed.

Numerous studies in the 1930s reported feeding fats of varying composition to study the effects primarily on milk fat composition, but some also investigated fat yield. Brown and Sutton (1931) fed up to $400 \mathrm{~g}$ daily of menhaden oil to one low-producing Holstein cow; within $4 \mathrm{~d}$ of feeding, both milk yield and fat percentage decreased precipitously. The authors showed by chain length and unsaturation measures that fish oil fatty acids were incorporated into the milk fat. Other authors evaluated effects on milk fatty acid composition of feeding other fish oils (McCay and Maynard, 1935), corn oil (Sutton et al., 1932), or fats of varying degrees of unsaturation (Maynard et al., 1936). In the latter study, milk fat iodine number changed in the direction of the supplement within $24 \mathrm{~h}$ of feeding. Moore et al. (1945) briefly reviewed effects of supplemental fats and oils on milk fat percent and undertook studies on amounts and frequency of feeding cod liver oil. They observed that more saturated fats tended to increase milk fat percent, whereas more unsaturated fats lowered milk fat percent and the milk fat was more un- saturated, confirmed by measuring iodine number. Cod liver oil depressed fat percent, or when hydrogenated, did not change fat percent. When cod liver oil was fed in 12 doses/d, milk fat percent of most cows was not changed. Moore et al. (1945) concluded that cows can hydrogenate unsaturated oils to some extent during digestion and absorption, but are unable to accommodate large amounts, which, in principle, was confirmed by later research. With considerable variability noted in the 1930s and 1940s among fat sources and their effects on lactation, later research on fat feeding turned to understanding the key metabolic differences among fat sources that account for this variability.

Shaw and Ensor (1959) reevaluated the effect of supplementing cod liver oil on milk fat yield. Whereas Hilditch (1956) had attributed the depressing effect to the long-chain (>C18) UFA of cod liver oil poisoning the fat synthesis mechanisms in the udder (because hydrogenation of cod liver oil eliminated the fat-depressing effect), Shaw and Ensor (1959) showed that both cod liver oil and linoleic acid depressed rumen acetate proportion and milk fat percent, contributing to a growing body of studies exploring relationships between ruminal production of volatile fatty acids, acetate:propionate ratio, and milk fat depression (Van Soest, 1963).

\section{FAT SOURCES BECOME MORE WIDELY AVAILABLE}

As petroleum-based detergents became available after World War II, the availability of tallow increased greatly and prices were low, resulting in increased opportunities for its use in animal feeds, among other uses. At the same time, vegetable oils (especially the soapstocks) generated in refining of corn and soybean oils were competing for animal feed use. Although the latter were quickly adapted by the broiler industry, they gained some limited use in ruminant diets, convenient to some because they could be handled as liquids. Also gaining attention as fat supplements for ruminants were whole seeds, especially whole cottonseed and soybeans. Later came studies on whole sunflower, canola, and flax seeds. Whole cottonseed quickly became a favorite supplement in dairy rations, because in addition to being a good source of protein and energy, it promotes stable rumen function or improves it (Coppock et al., 1987).

Schingoethe and Casper (1991) summarized several lactation studies to show that supplementing TMR with extruded soybeans, sunflower seeds, or whole sunflower increased milk yield when fed from 4 to 16 wk of lactation, although both milk fat percent and protein percent were decreased. Interestingly, the fat supplement effects carried over, resulting in higher mature-equivalent milk yield over a 305-d lactation. Extruding whole oilseeds 
for lactating cows consistently lowers milk fat percent because extrusion releases excessive amounts of free oil in the rumen. However, whole or cracked roasted soybeans are a very acceptable energy source for lactating cows (Faldet and Satter, 1991; Tice et al., 1993, 1994; Jenkins and McGuire, 2006). A useful summary of fat in forages is provided by Glasser et al. (2008). Rabiee et al. (2012) quantified, using meta-analysis and meta-regression, the effects of supplementation with fats on milk production and milk components by dairy cows. Of 38 papers containing 86 comparisons, 5 groups of fats were evaluated: tallow, calcium salts of palm fat, oilseeds, other calcium salts, and prilled SFA. Responses to fat feeding were highly heterogeneous for all variables studied and heterogeneity was present within responses from individual fat groups. Lower DMI combined with higher milk and milk fat production showed that fats could improve efficiency of milk production, including when fed with recombinant bST (Schneider et al., 1990).

\section{THE LIMITATIONS OF FATS BEGIN TO EMERGE}

\section{Digestibility Effects}

Studies of fat digestibility were undertaken in the 1940s (Lucas and Loosli, 1944; Swift et al., 1947, 1948). All reported that added oil decreased fiber digestion and increased fat digestibility; however, all were compromised by the lack of recognition (Ward and Reid, 1948) that much of fecal fat occurs as the insoluble calcium soap, which is not measured by classic ether extraction procedures and thus overestimates fatty acid digestibility. Studies before the report of fecal calcium soaps and many later must be carefully evaluated as to methodology of fecal fat extraction; if acidic extraction is not used, results overestimate fatty acid digestibility (Palmquist and Jenkins, 2003) and this remains an issue to this day.

Many studies in the 1950s addressed the effects of added vegetable oils on fiber digestion in the rumen. Of special note, the depressing effect of fat on cellulose digestibility in vitro was shown to be reversed by addition of alfalfa ash (Brooks et al., 1956), and fat effects on fiber digestion in vivo were reversed by calcium addition (White et al., 1958). Tillman and Brethour (1958) showed that addition of corn oil to the diet of sheep decreased Ca digestibility and retention. Davison and Woods (1960) reported that all SFA from C8 to C18 inhibited cellulose digestion in vitro. el-Hag and Miller (1972) later modified these conclusions in an elegant series of studies, showing that C10 to C14 saturates and the $\mathrm{C} 18$ unsaturates inhibit cellulose digestion and that the effects are reversed by addition of calcium chlo- ride, except for $\mathrm{C} 10$. Status of knowledge on digestion and utilization of fat by ruminants was summarized by Palmquist and Jenkins (1980). Palmquist (1991) noted that fatty acid digestibility is curvilinear at high intakes, especially of high $\mathrm{C} 18$ vegetable fats. Whereas all dietary fatty acids and $\mathrm{C} 18$ biohydrogenation $(\mathbf{B H})$ products have similar intestinal digestibilities (Moate et al., 2004; Glasser et al., 2008), at high intestinal flows of C18:0, intestinal digestibility declines quadratically (Glasser et al., 2008) or linearly (Boerman et al., 2015). This is surely caused by low solubility of C18:0 in intestinal micelles, causing C18:0 to fall out of solution as more unsaturated or shorter-chain fatty acids are absorbed in the jejunem (Lough, 1970; Glasser et al., 2008).

\section{Rumen Fermentation}

Key to studying rumen fermentation and microbiology was the development of the permanent rumen fistula, as demonstrated by Monroe and Perkins (1939) at The Ohio Agricultural Experiment Station in their analysis of rumen $\mathrm{pH}$ fluctuations (Figure 1). Lorraine Gall was an early investigator to address microbiology of the rumen (Gall et al., 1947) and introduced the methodology in Ohio with Wise Burroughs and Paul Gerlaugh (Gall et al., 1949a,b). These investigators were later joined by Marvin Bryant and Milt Allison at USDA and Burk Dehority in Ohio, all premier rumen microbiologists who published in the Journal of Dairy Science.

Ready access to rumen contents was essential to pursue the cause of depressed milk fat percent when certain oils were fed to cows. Most of the earlier research of effects of lipids on rumen microbial metabolism was published by researchers in the United Kingdom (Dawson and Kemp, 1970; Harfoot, 1978). Studies published in the Journal of Dairy Science were by Katz and Keeney (1966), who reported numerous octadecenoic isomers in rumen content, and Sklan and Budowski (1974), who described fundamental ruminal $\mathrm{BH}$ requirements for temperature, $\mathrm{pH}$, and cofactors. Work continued on fatty acid effects on rumen fermentation such as effects of fat saturation and esterification (Steele et al., 1971) and the role of dietary fiber in alleviating fermentation problems from added fat (Doreau et al., 1991; Bateman and Jenkins, 1998; Avila et al., 2000).

\section{RUMINAL BH IS DESCRIBED}

A brief history of the development of research on ruminal BH is provided in Palmquist (2007) and Jenkins and Harvatine (2014). Ruminal BH of dietary UFA was first described in 1951 by Reiser (1951) and in detail 
by Shorland et al. (1957), although its occurrence had been speculated much earlier. Certainly, the development of GLC shortly thereafter advanced the description of BH. Detailed studies by Tove's group (Kepler et al., 1966) showed that BH of linoleic acid (cis-9,cis-12 18:2) was initiated by isomerization of the cis-12 double bond to trans-11, followed by hydrogenation of the cis-9 double bond. Subsequent studies showed that isomerization of the cis-12 bond before the hydrogenation step is typical in fatty acids containing cis-9,cis-12 methylinterrupted unsaturation. Research on chemical and microbiological BH processes was active in the 1960s and 1970s (Dawson and Kemp, 1970; Harfoot, 1978). The demonstration by Harfoot et al. (1974) that fatty acids are adsorbed to surfaces of feed particles and microbial cell walls in a competitive manner was key for several reasons: the $\mathrm{BH}$ process takes place on feed par-

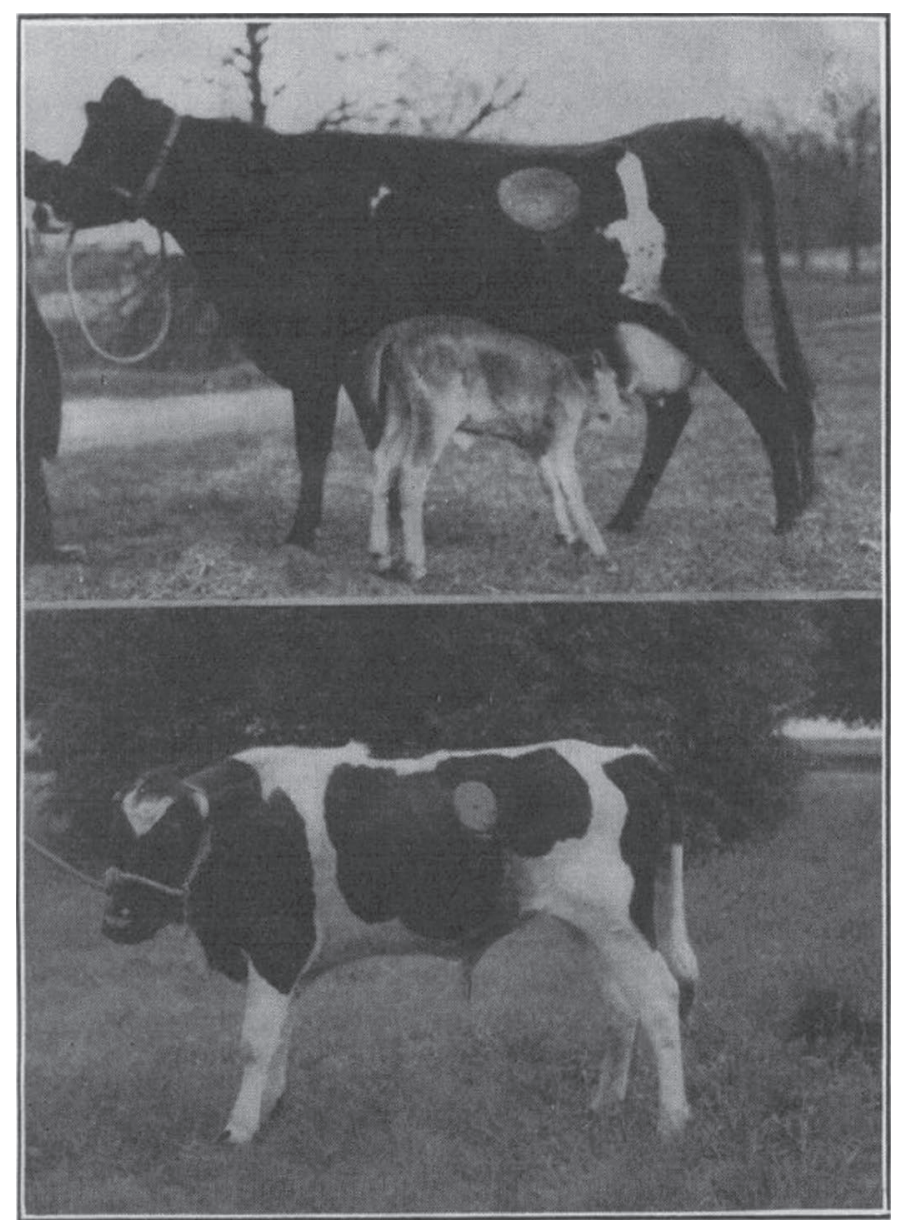

Figure 1. Photographs showing rumen fistulation of cows in studies done at The Ohio Agricultural Experiment Station in Wooster Ohio. The availability of ruminally fistulated cows was instrumental in advancing studies examining the effect of fat feeding on rumen fermentation and digestion. Reprinted from Monroe and Perkins (1939) with permission. ticle surfaces and adsorption to feed particles removes fatty acids from the medium and decreases attachment to and inhibition of microbes; and it explained the beneficial effects of high-forage diets when fat supplements are fed. The source and unsaturation of fatty acids influence the $\mathrm{BH}$ process. Feeding whole soybeans to lactating cows increased yield and percentage of milk fat, but when soybean oil was fed, a decrease in amount and milk fat percentage was decreased (Steele et al., 1971). When fats are fed as glycerides, especially as whole seeds, fatty acids are released slowly, unesterified fatty acid concentrations remain low, and UFA are biohydrogenated completely to stearic acid (Morales et al., 2000). When fats are fed as free oil, or as free acids, an intermediate of $\mathrm{BH}$, trans-11 18:1 (vaccenic acid) accumulates, and further $\mathrm{BH}$ to stearic acid proceeds slowly. Thus, BH takes place as 2 separate steps, by different organisms; when vaccenic acid accumulates, the final BH step is inhibited (Moate et al., 2008). The result is that under feeding conditions in which free unsaturated oils or fatty acids are fed, a large amount of vaccenic acid and numerous other trans-UFA isomers are formed and absorbed. Whereas Jenkins and Bridges (2007) concluded that all supplemental fats, protected or unprotected, are biohydrogenated to a similar extent (C18:1, 86\%, C18:2, 82\%, and C18:3, 86\%), some authors have reported increased UFA contents in milk fat when feeding whole seeds, especially whole raw (Barletta et al., 2016), roasted (Timmons et al., 2001) or steam-flaked soybeans (Bruns et al., 2015). As noted by Jenkins and Bridges (2007), increasing the amount fed of unprotected fats will increase duodenal flow of unsaturated fats.

\section{OVERCOMING BH TO MODIFY MILK FAT COMPOSITION}

Concerns from the medical community beginning in the 1950s that saturated animal fats cause high blood cholesterol and cardiovascular diseases brought intense pressure on milk producers and processors to search for opportunities to decrease the proportion of saturated fats in dairy products. This led researchers in Australia to develop animal feeds based on unsaturated oils protected from ruminal $\mathrm{BH}$. The protection process involved coating oil with vegetable proteins or casein, followed by treating with alkali, formaldehyde, and drying (Cook et al., 1972). The product was inert in rumen contents but the aldehyde cross-links were labile at the acid $\mathrm{pH}$ of the abomasum, releasing the unsaturated oils for intestinal digestion. This was an effective process (Ashes et al., 1992, 1997), and led to an abundance of research worldwide on effects of feeding these products on fat composition of milk and 
meat (McDonald and Scott, 1977). Further, a means was made available to stimulate research on ruminant lipid metabolism. Milk fat with $20 \%$ or greater linoleic acid could be produced (Wood et al., 1974), but it was soon shown that such products were not stable due to potential oxidation. Because of product-processing difficulties, regulatory issues concerning use of formaldehyde in food production, and probably costs of production, such polyunsaturated foods never became commercially available. As understanding of milk fat synthesis progressed and the effect of supplementing various fats and oilseeds became apparent, and consistent with an increasing demand from the public for low-fat dairy products, research on alternate methods to modify milk fat composition by feeding conventional fat sources occurred (Grummer, 1991; Palmquist et al., 1993).

Feeding any long-chain fatty acid supplement decreases the short- and medium-chain fatty acids in milk and increases the content of mainly $\mathrm{C} 18$ fatty acids, whereas feeding supplements high in C16 increase that fatty acid to a greater extent than increasing C18 fatty acids. Timmons et al. (2001) measured fatty acid composition of diets from 20 dairy farms that fed from 0 to $15 \%$ of feed DM as roasted whole soybeans, focusing on C18:2 and C18:3 contents of soybeans, diets, and milk fat. Contents of both $\mathrm{C} 18: 2$ and $\mathrm{C} 18: 3$ in milk fat increased linearly, to nearly double, at the highest content of roasted soybeans in the diets. As the percentage of roasted whole soybeans increased in diets, C18:2 increased in the DM, whereas little increase was observed for C18:3. The observation of increased milk fat 18:3 with only a small increase in intake from the roasted soybeans was explained by Morales et al. (2000), who observed less $\mathrm{BH}$ intermediates and higher C18:0 and C18:2 in milk of cows fed whole roasted soybeans compared with cows fed tallow. They concluded that fatty acid release from the heat-treated soybeans proceeded slowly, allowing complete BH of UFA, while simultaneously some UFA were not released from the seed, allowing these to pass the rumen unchanged. Global effects of feeding different sources of fat on milk fatty acid composition were reviewed in detail by Glasser et al. (2008) and Hurtaud et al. (2010).

In later years, interest in modifying milk fat composition moved more in the direction of functional foods. The term "functional foods" was first used in Japan in the 1980s as a legal definition for foods that have specific physiological effects. Pariza's group (Ha et al., 1987; Pariza, 1999) discovered that conjugated cis and trans isomers of linoleic acid (CLA) have potent anticancer properties. Parodi (1994) observed that the biologically active CLA isomer cis-9,trans-11 18:2 is found in milk fat (Parodi, 1977) and could be synthesized from vaccenic acid (trans-11 C18:1), a common milk fat component. These key discoveries led to intense research activity among dairy scientists to develop effective diets that promote higher concentrations of vaccenic acid and cis-9,trans-11 18:2 (later given the trivial name "rumenic acid") in milk fat. These studies coincided with the period of renewed interest in ruminal $\mathrm{BH}$ as related to ruminal synthesis of trans isomers of C18 UFA and low milk fat syndrome (Bauman and Griinari, 2001). Other components of milk that have drawn interest for their functionality include butyric acid, phytanic acid (Hellgren, 2010), and other branched-chain fatty acids, casein, whey proteins, oligosaccharides, and many more (Clare and Swaisgood, 2000; Mills et al., 2011; Kanekanian, 2014; Visioli and Strata, 2014; Beltrán-Barrientos et al., 2016).

\section{Feed Intake Limitations}

It was not until later that attention turned to the effects fat on feed intake. Heinrichs et al. (1982) showed that adding $10 \%$ tallow or animal-vegetable blend to a concentrate fed at $50 \%$ of dietary DMI caused cows to eat smaller initial meals, compensated by more frequent, small spontaneous meals. No difference in total DMI occurred. Drackley et al. (1992) infused SFA, MUFA, and PUFA into the abomasum of lactating cows, and intake depression increased with increasing chain length and unsaturation. Benson et al. (2001) infused UFA and reported that although DMI was reduced, ME intake was not; C18:2 was more effective than C18:1, and unesterified fatty acids had a greater effect than esterified to reduce intake. Litherland et al. (2005) infused soy oil abomasally as fatty acids or glycerides at 0, 200, 400, or $600 \mathrm{~g} / \mathrm{d}$. Dry matter intake and milk and fat yields decreased when either form of oil was infused, although the rate of decline was greater when fatty acids were infused. All de novo synthesized fatty acids except C4 and C6 were decreased as the amount of oil in either form increased. Numerous authors have reported that calcium soaps of palm fatty acids depressed intake compared with SFA. Considering that calcium soaps of palm contain $\sim 40 \% \mathrm{C} 18: 1$ and $\sim 8 \% \mathrm{C} 18: 2$ and that $\mathrm{BH}$ approximates $50 \%$ in the rumen (Klusmeyer and Clark, 1991; Wu et al., 1991), the higher unsaturation of fatty acids appearing in the intestine may depress intake. Choi and Palmquist (1996) reported that highfat diets increased circulating cholecystokinin (CCK), and Choi et al. (2000) showed that CCK depresses DMI in nonlactating heifers. Neither Benson et al. (2001) nor Litherland et al. (2005) observed increased plasma CCK when oil was infused abomasally. In an intensive and extensive series of studies, Allen and colleagues (Stocks and Allen, 2012, 2014; Allen, 2014; Piantoni et 
al., 2015c) have shown that DMI is related to rates of change in plasma nonesterified fatty acids and hepatic concentrations of acetyl-CoA after feeding when energy intake is limiting.

\section{RECOMMENDATIONS FOR FEEDING FAT}

With increased awareness of the limitations of feeding UFA came recommendations for limiting their content in lactation rations. Although the primary reason to use fat in diets for lactating cows may be to increase energy density, using fat increases flexibility for ration formulation. Palmquist and Conrad $(1978,1980)$ used fat to maintain the energy concentration of the diet while decreasing grain and increasing forage contents. This increased milk fat percentage without loss of milk yield. This approach is also applicable in later lactation to prevent excess fattening of cows.

A common question is how much fat should be fed. As noted above, Maynard (1937) observed that cows fed less fat than was produced in the milk had decreased milk yield. Does that observation, in cows producing no more than 18 to $25 \mathrm{~kg} / \mathrm{d}$ of milk, apply to today's cows? Considering that approximately one-half of dietary fat is transferred to milk fat and that a similar amount of C16 and C18 fatty acids in milk is derived from dietary fatty acids, Maynard's (1937) observation appears to be valid. Two recent papers provide interesting data to challenge that idea: Greco et al. (2015) fed $\sim 950 \mathrm{~g} / \mathrm{d}$ of supplemental fat to cows yielding 1.5 to $1.7 \mathrm{~kg} / \mathrm{d}$ of milk fat; C16:0 content of the milk fat was 36 to $38 \%$ of total milk fatty acids, reflecting high de novo synthesis, typical for cows fed insufficient fat (Banks et al., 1976). Stoffel et al. (2015) fed 600 to $800 \mathrm{~g} / \mathrm{d}$ of supplemental fat (total diet fat $<3 \%$ ) to cows yielding 1.3 to $1.5 \mathrm{~kg}$ of fat per day. The C16:0 content of the milk fat was 27 to $32 \%$ of total milk fatty acids, considered to be within a normal range. In the latter study, Stoffel et al. (2015) treated the cows with recombinant bST, which apparently stimulated both de novo synthesis and body fat mobilization (mainly C18 fatty acids) to achieve high milk fat yields and normal composition despite low fat intake. Although both studies achieved high milk and fat yields with less than optimal fat intake, on balance it seems advisable to feed fat at higher levels than reported by Greco et al. (2015) and Stoffel et al. (2015) to ensure maintenance of both milk production and appropriate body condition. Thus, Maynard's observation to feed as much fat as the cow produces remains a useful rule of thumb for feeding.

Kronfeld (1976) estimated, by modeling metabolic pathways, that cows should be fed fat at $16 \%$ of ME intake to achieve maximum energetic efficiency. If fat is fed in an amount equal to that in milk, metabolic

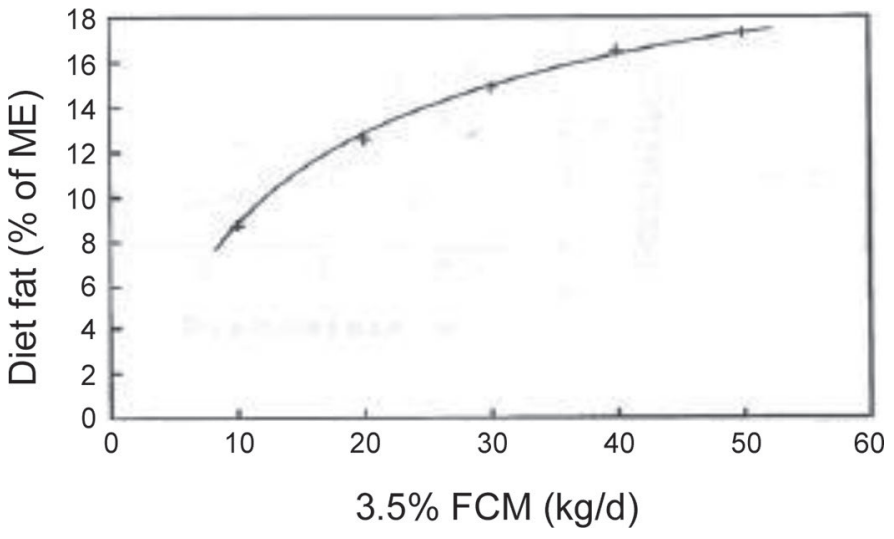

Figure 2. Energetic efficiency of milk synthesis increases quadratically with increasing milk yield when fat is fed in amounts equal to milk fat yield. According to Kronfeld (1976), optimum metabolic efficiency is achieved when dietary fat $=16 \%$ of ME intake. Source: D. L. Palmquist, unpublished data (1992).

efficiency (according to Kronfeld) increases from less than $8 \%$ of $\mathrm{ME}$ at $10 \mathrm{~kg} / \mathrm{d}$ to greater than $18 \%$ of $\mathrm{ME}$ at $50 \mathrm{~kg} / \mathrm{d}$ of $3.5 \% \mathrm{ECM}$ (Figure 2). Dietary fat is transferred to milk fat without the energetic cost of synthesis, recognized more than a century ago by Fingerling and associates (Reid, 1956), described in detail by Baldwin et al. (1980), and demonstrated in practice by several studies (Lock et al., 2013).

Even at low levels of fat supplementation, fats may depress ruminal fiber digestion, or more likely promote formation of fatty acid isomers that cause milk fat depression. Jenkins and Harvatine (2014) developed a formula to calculate the amount of unsaturated fat that may be safely added to lactation rations. It takes into account the total UFA in the supplement and the NDF content of the dietary DM as follows:

Fat to include in the ration $(\%)=$

$4 \times \% \mathrm{NDF} \div$ sum of $\%$ UFA in the supplement.

From early on, it was assumed that fat supplementation is necessary only during the period of lactation when cows are in negative energy balance. However, some studies showed that supplemental fat feeding from parturition depressed feed intake (Ruegsegger and Schultz, 1985; Jerred et al., 1990), suggesting that fat should not be fed until after 6 wk of lactation. It was thought that perhaps the total supplemental and mobilized fat was greater than the ability of the cow to metabolize the fat (Palmquist, 1994). Recent research has shown that in early lactation, supplemental fat fed with high NDF diets is deposited in body reserves, perhaps via insulin stimulation, whereas supplemental fat fed with low NDF diets increases milk yield (Weiss and Pinos- 
Rodriguez, 2009; Piantoni et al., 2015a,b). Important in these studies is that SFA were supplemented at low levels $(<3 \%$ of DM).

\section{THE DAWN OF BYPASS FATS}

Bypass fats emerged from the growing interest in the possibility of enhancing diet energy density from added fat, along with the desire to minimize negative effects of unsaturated fats on rumen fermentation and digestion (Appendix Table A1). The idea of bypass fats began when Palmquist and Conrad (1980) noted that calcium content was the most significant dietary factor affecting fiber digestibility in lactation rations; this led to studies on the interactions between fat and calcium content of the diet on fiber digestion (Jenkins and Palmquist, 1982) and specifically on the rates of calcium salt formation in the rumen. It was found that although selection of fatty acids and calcium source could influence rates of insoluble calcium salt formation (thus rendering fatty acids inert in the rumen), the resulting extents of soap formation were insufficient to prevent effects of dietary UFA on fiber digestion. Further studies showed the effectiveness of feeding preformed calcium salts (soaps) of fat (Figure 3) and the ability of the animal to efficiently digest the preformed soaps (Jenkins and Palmquist, 1984). These studies led to a period of intense research on what became known as "rumen-inert" fats. As time passed, the term "bypass fats" gained popularity over the more technically accurate "rumen-inert" terminology to describe fats that minimize rumen fermentation problems. Dozens of in vitro and in vivo studies followed in the Journal of Dairy Science, evaluating Ca salts of fatty acids on lactation performance. The survival of Ca salts over the decades was a combination of their inertness in the rumen, positive effects on lactation (Rabiee et al., 2012), ease of handling and transportation, and backing from extensive research.

With the door open for bypass fat from the success of Ca salts, alternative bypass fats were developed commercially that were based mainly on SFA, usually prilled fats consisting largely of palmitic and stearic acids. These provided high energy without the risk of disrupting rumen fermentation often reported with UFA. Grummer (1988) fed prilled fatty acids and Ca salts to cows and concluded that both were inert in the rumen when fed at $3.5 \%$ or less of the ration DM. Numerous commercial fat products based on Ca salts or prilled SFA have become available to the dairy industry since their first development in the 1980s. Several of these have had ongoing success due largely to their consistency and quality control, availability of product, and a base of research trials documenting their effectiveness.
Saturated triglycerides also were tested for effectiveness as alternate bypass fats but were shown to have very low digestibility, attributed to the insoluble nature of low iodine value (IV) fats that could not be hydrolyzed or absorbed in the small intestine. Firkins and Eastridge (1994) showed that an IV of $>30$ is required for acceptable digestibility.

\section{FEEDING FATS AND REPRODUCTION}

With the realization that energy restriction compromises reproductive performance, studies gained momentum in the early 1990s to evaluate effects of feeding fat on reproduction. Carroll et al. (1990) fed 5\% prilled fatty acids to Holstein cows and reported increases in plasma progesterone during the luteal phase. A later review by Grummer and Carroll (1991) summarized the effects of dietary fat on reproductive performance of dairy cattle. At about the same time, the effects of fat supplements on reproduction were being evaluated at the University of Florida. Lucy et al. (1991) reported that feeding calcium soaps of fatty acids to cows altered the diameter of follicles after progesterone treatment (Figure 4).

Results were showing that dietary fats could influence the reproductive status of dairy cows, including increasing the number and size of ovulatory follicles, plasma concentration of progesterone, and decreasing the secretion of prostaglandin $\mathrm{F}_{2 \alpha}$ metabolite

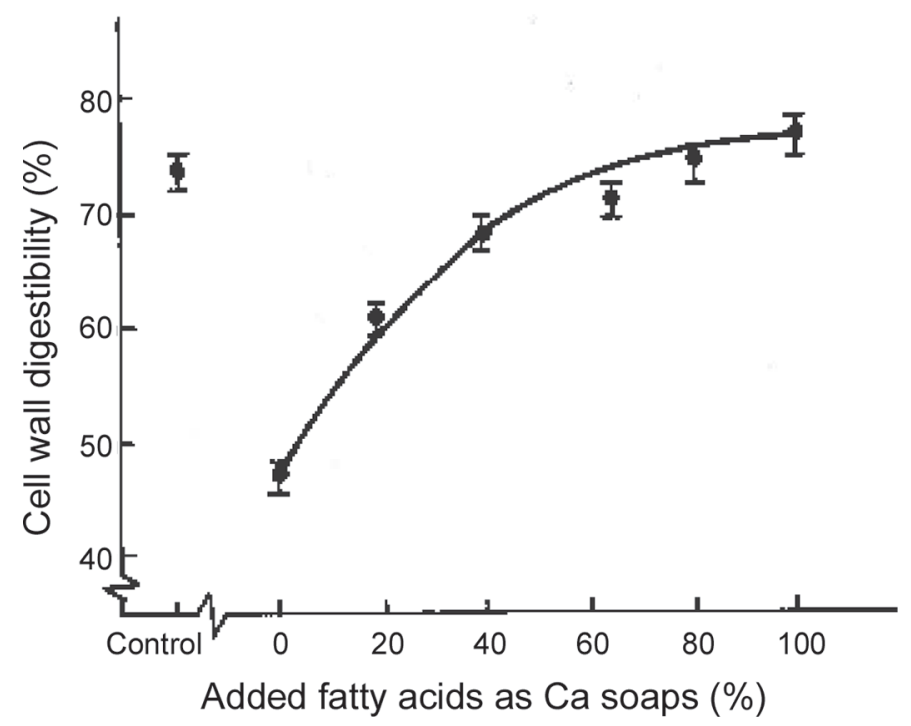

Figure 3. Figure presented at the XIIth World Congress on Diseases of Cattle, Amsterdam, the Netherlands (Palmquist and Jenkins, 1982) depicting the value of calcium soaps of fatty acids in alleviating depression in cell wall digestibility by $100 \mathrm{mg} / \mathrm{g}$ of fatty acids in vitro. Results from this trial formed the basis of feeding preformed calcium salts of fatty acids as a bypass fat to prevent rumen fermentation and digestion problems. 
(PGFM), resulting in increased lifespan of the corpus luteum (CL) and improved fertility (Staples et al., 1998). Many of these effects can be related to increasing intake of essential fatty acids through effects on prostaglandin synthesis; this has led to increased research on the role and requirement for essential fatty acids in reproduction. Fouladi-Nashta et al. (2007) synchronized estrous cycles in cows fed a silage-based diet supplemented with either low $(200 \mathrm{~g} / \mathrm{d})$ or high $(800 \mathrm{~g} / \mathrm{d})$ amount of fat. Oocytes were collected, matured, fertilized, and cultured to the blastocyst stage in vitro. The high-fat diet reduced numbers of small and medium follicles without any effect on the quality of oocytes or cleavage rate and improved blastocyst production from matured and cleaved oocytes. Blastocysts from the high-fat group had significantly more total, inner cell mass, and trophectoderm cells than the low-fat group. Higher milk yields were associated with reduced developmental potential of oocytes in cows given a lowfat diet. Provision of a high-fat diet buffered oocytes against reduced developmental potential, resulting in significantly improved developmental potential.

Modifying intakes of n- 6 and n-3 fatty acids regulates the balance of 2- and 3-series prostaglandins. Establishing pregnancy after fertilization requires continued progesterone secretion from the CL; high concentrations of $\mathrm{PGF}_{2 \alpha}$ cause regression of the CL, with loss of the conceptus before it is established in the uterus. Increasing the availability of linoleic or linolenic acid decreases synthesis of arachidonic acid (Chagas et al., 2007), the precursor for $\mathrm{PGF}_{2 \alpha}$, in turn decreasing its synthesis. Also, higher linolenic acid increases synthesis of eicosapentaenoic acid (EPA), a precursor of the 3-series of

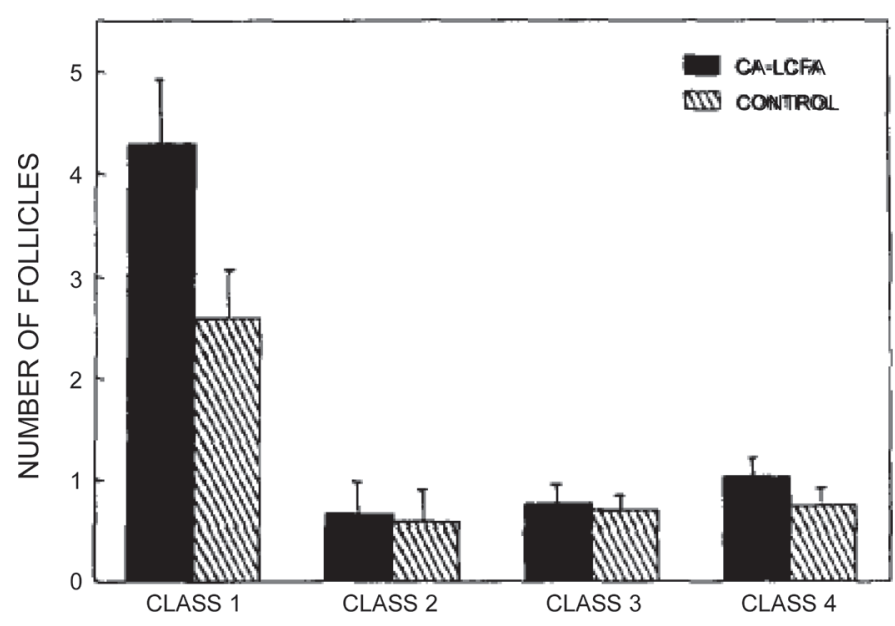

Figure 4. Early results from reproduction studies at the University of Florida by Lucy et al. (1991), showing the increase in number of large follicles when cows were fed calcium salts of long-chain fatty acids (CA-LCFA). Reprinted with permission. prostaglandins that counteract the effects of $\mathrm{PGF}_{2 \alpha}$. Providing EPA directly by feeding fish oil has a similar effect. More subtle effects of EPA in these processes have been reviewed (Chagas et al., 2007; Wathes et al., 2007).

An early return to ovarian activity postpartum may not be desirable in dairy cows. Prostaglandin $\mathrm{F}_{2 \alpha}$ is necessary in the postpartum process of involution of the uterus and restoration of tissues for the next pregnancy. Absence of ovarian activity during this period appears to enhance the process of involution. Thatcher et al. (2006) suggested that a strategy of dietary supplementation with functional nutrients to increase availability of prostaglandin that would enhance general immunocompetence and neutrophil function could be an attractive means to manage uterine infections and subsequent infertility. Cows that developed endometritis had lower PGFM concentrations during the early postpartum period (i.e., 0-14 d postpartum), perhaps contributing to a reduction in neutrophil function that compromises the ability of the uterus to prevent or manage infections. After completion of uterine involution, sequential ovulations would be a goal toward normal fertility. To test these concepts, as summarized by Thatcher et al. (2006), cows were supplemented for 28 d prepartum or only postpartum with a calcium salt of fatty acids containing $28 \%$ linoleic acid, fed until $10 \mathrm{wk}$ postpartum. Those cows supplemented prepartum had significantly higher PGFM in serum for the first $12 \mathrm{~d}$ of lactation than cows in other groups and fewer health problems in the first $10 \mathrm{~d}$ postpartum, whereas conception to first insemination after induced ovulation at 72 d was greater $(P<0.09)$ for all supplemented groups compared with no supplement. A note of caution is warranted: if supplementation of linoleic acid is excessive, desaturation and chain elongation to arachidonic acid, the precursor of $\mathrm{PGF}_{2 \alpha}$, will be inhibited.

A further concept of manipulating essential fatty acid availability in reproductive management is to feed a high linoleic fatty acid source from $28 \mathrm{~d}$ prepartum to 28 d postpartum, followed by a high n-3 source, preferably fish oil, from 28 to $100 \mathrm{~d}$ of lactation. The first would provide an environment as described above, whereas following with a high n-3 source should decrease the 2 -series and increase the 3 -series prostaglandins to improve the environment for embryo implantation and survival. Collectively, these studies suggest that feeding fats enriched in selected UFA, beginning in the dry period and continuing in the postpartum period, improves postpartum health and milk production, as well as the development of bovine embryos and subsequent pregnancy rates. The beneficial effects on reproductive responses may be due to a hastened restoration of the postpartum reproductive system to support embryo 
development (Thatcher et al., 2006). Silvestre et al. (2011) applied these principles on a commercial dairy. Holstein cows $(\mathrm{n}=1,380)$ were assigned randomly to be fed either calcium salts of palm oil or safflower oil from $30 \mathrm{~d}$ prepartum until $30 \mathrm{~d}$ postpartum and further randomized to receive either calcium salts of palm oil or fish oil from 30 to $160 \mathrm{~d}$ postpartum. Supplementation of calcium salts of fatty acids was at $1.5 \%$ of dietary DM. Silvestre et al. (2011) concluded,

"plasma $\mathrm{PGF}_{2 \alpha}$ metabolite was greater in cows fed calcium salts of safflower oil (high n-6 source) at 4 and $7 \mathrm{~d}$ post-partum. Pregnancy per AI at 32 and $60 \mathrm{~d}$ post first AI was not affected by diets, but pregnancy loss was less in cows fed calcium salts of fish oil (high n-3 source). At second AI, pregnancy was greater in cows fed fish oil soap at $32 \mathrm{~d}$ and in cows fed the safflower oil-fish oil sequence at $60 \mathrm{~d}$ post AI. Pregnancy loss after second AI was not affected by diets. Overall pregnancy per AI was greater in cows fed calcium salt of safflower oil followed by calcium salt of fish oil at $60 \mathrm{~d}$ of pregnancy and pregnancy loss was reduced in cows fed fish oil. Monthly milk yield was greater $(0.7 \mathrm{~kg} / \mathrm{d})$ in safflower oil-fed cows. In conclusion, strategic feeding of calcium salt of fatty acids during the transition and breeding periods can benefit fertility and milk production of lactating dairy cows."

\section{THE CONTRIBUTION OF DIETARY FAT TO MILK FAT SYNTHESIS AND COMPOSITION}

Questions about the origin of fat in milk surfaced early in the Journal of Dairy Science and soon led to studies examining the role of dietary fats in milk synthesis. Early studies on composition of milk fat were slow, tedious, and often not quantitative. Hilditch (1956) contributed much data to the description of milk fat composition. Fatty acids were separated by fractional distillation after precipitation of unsaturates by addition of urea. Identification of UFA was accomplished by isomerization and infrared photometric absorption. Fatty acid chain length of glycerides was characterized by saponification number and unsaturation by iodine number; milk fat short-chain fatty acids were characterized relatively, but not quantitatively, by the ReichertMeissl number, though the latter could be quantified by steam distillation and titration. Application of these methods to milk fat analysis is described in a series of papers by Smith and Jack (1954a,b) and Smith et al. (1954). In 1952, James and Martin published the first article on a procedure for GLC that revolutionized the analysis of fatty acids. Although it took some time for the method to become routine for milk fat analysis (James and Martin, 1956), it has become an essential tool for milk fat research (Patton et al. 1960; Smith, 1961). A useful illustration of the effect of GLC on understanding milk fat composition is to compare the reviews by Garton (1963) and Jensen (2002) on fatty acids in milk fat. Whereas Garton (1963) reported $\sim 35$ milk fatty acids plus an equal number unidentified, Jensen (2002) reported over 400 fatty acids in milk.

Metabolic pathways for intramammary fatty acid synthesis, especially for sources of carbon, were relatively well known by 1970 (Storry, 1970); however, the mechanisms for supply of NADPH required for fatty acid synthesis were less certain, as it was known that the citrate lyase cycle is not functional in the ruminant mammary gland. The question was resolved by Bauman et al. (1970), who described the NADP-isocitrate dehydrogenase cycle. This pathway conserves glucose for ruminants by a combination of mitochondrial and cytosolic enzymes and using rumen-derived acetate to furnish carbons for lipogenesis as well as a portion of the reducing equivalents needed for fatty acid synthesis.

Although it was clear that part of $\mathrm{C} 16$ and all C18 fatty acids were of exogenous source (Palmquist et al., 1969), utilization of the long-chain dietary fatty acids remained largely undefined. In a nicely designed study, Banks et al. (1976) compared milk yields of C16 and $\mathrm{C} 18$ fatty acids as a function of their intakes from low fat or fat-supplemented diets. They reported a linear relationship between $\mathrm{C} 18$ intake and yield: $\mathrm{Y}=75+$ $0.54 \mathrm{X}, \mathrm{R}^{2}=0.92$, for 20 pairs of data, where $\mathrm{Y}=$ yield of $\mathrm{C} 18$ fatty acids, and $\mathrm{X}=$ total $\mathrm{C} 18$ intake. Thus, at zero intake of $\mathrm{C} 18$ fatty acids, milk yield would include $75 \mathrm{~g} / \mathrm{d}$ of $\mathrm{C} 18$, and $54 \%$ of $\mathrm{C} 18$ consumed would be transferred to milk fat. The authors compared this transfer quotient with data from the literature that, rather consistently, was only $\sim 0.3$. The lower value would indicate that, in general, intakes of $\mathrm{C} 18$ reported in the literature exceeded capacity for milk secretion. The transfer coefficient of Banks et al. (1976) is identical to values observed by LaCount et al. (1994) for transfer of C18:1 from intestinally infused canola oil or high oleic sunflower oil to milk fat $(\mathrm{Y}=184.5+$ $\left.0.541 \mathrm{X}, \mathrm{R}^{2}=0.70\right)$, and for transfer to milk fat of $\mathrm{C} 18: 2$ from the same oils $\left(\mathrm{Y}=22.2+0.527 \mathrm{X}, \mathrm{R}^{2}=0.88\right)$. Moallem et al. (2012) reported transfer of linolenic acid from infused flaxseed oil of 0.44 to 0.46 . Consistent with these transfer estimates, radiotracer studies using labeled palmitic and linoleic acids injected ruminally or intravenously by Palmquist and Conrad (1971) and Palmquist and Mattos (1978) showed, by kinetic analysis, that $90 \%$ of long-chain fatty acids in milk (45-50\% of total milk fat) are derived directly from the diet. Further research (Kleppe et al., 1988; Pullen 
et al., 1989, 1990) showed that very little of circulating plasma fatty acids is incorporated into liver very low density lipoprotein (VLDL) triglycerides and secreted into plasma in ruminants. Although a net transfer of plasma nonesterified fatty acids across the mammary gland does occur, the amount of fatty acids mobilized from adipose tissue that contribute to milk fat synthesis is relatively small, except during early lactation when body fat mobilization is very great. Drackley et al. (2007), infusing high oleic sunflower oil fatty acids, achieved a milk fat C18:1 content of $57 \%$, indicating that the amount of this fatty acid in milk fat is not limited in the physiological range of content.

Banks et al. (1976) also plotted milk C16:0 against intake of $\mathrm{C} 16: 0$; when diets were supplemented with fat, C16:0 yields were less than that observed at low fat intake, showing that dietary fat inhibited mammary C16:0 synthesis. If dietary C16:0 is absorbed and utilized for milk fat synthesis similar to that for C18 fatty acids, then mammary inhibition of C16:0 synthesis by exogenous fatty acids would be on the order of $50 \%$, consistent with the observation by Banks et al. (1976) that supplemental diet fat inhibited the synthesis of fatty acids C6 to C14 by $40 \%$, whereas content of butyric acid in milk fat is relatively independent of dietary fat. Finally, they observed that in milk fat from cows on low-forage fat-depressing diets, the ratio of C18:1:C18:0 was excessively high; they postulated that a large portion of the C18:1 in such conditions could be trans C18:1, as had been proposed by Davis and Brown (1970).

It was recognized early that feeding fat often decreased milk protein percent, and this became a focus of research (DePeters and Cant, 1992). An in-depth study by Cant et al. (1993a,b) concluded that increased utilization of preformed fatty acids for milk fat synthesis spared glucose utilization for lactose synthesis, increasing milk yield and lactation efficiency without increasing mammary blood flow and AA uptake, thus diluting milk protein concentration. However, DePeters and Cant (1992) calculated that only $34.5 \%$ of the change in milk yield was responsible for milk protein dilution. Recent studies report that, though milk protein percent may be reduced, milk protein yield is not changed by feeding fat (Rabiee et al., 2012). Perhaps modern feeding practices when feeding supplemental fat, especially balancing diet AA, provide sufficient mammary AA supply to maintain protein yield.

\section{RUMEN BH YIELDS INTERMEDIATES THAT CAUSE MILK FAT DEPRESSION}

Low milk fat syndrome is a condition in which milk fat composition is altered and fat yield is reduced, usu- ally by 30 to $50 \%$, by certain feeding conditions. Such feeding conditions are varied but usually include diets characterized by low fiber or low effective fiber (ground or pelleted forages) intakes, high starch or high soluble carbohydrate diets, and unsaturated oils or oilseeds. Briefly, the past theories of milk fat depression included a shortage of dietary long-chain fatty acids, inadequate ruminal acetate production for the mammary synthesis of de novo fatty acids, overproduction of propionate in the rumen that caused an increase in insulin and shifted fat synthesis to adipose tissue, and reduced ruminal synthesis of vitamin $\mathrm{B}_{12}$ that increased methylmalonylCoA, a competitive inhibitor of fatty acid synthase. For all of these, skepticism remained about their validity after extensive research over many years exposed weaknesses and little support.

A breakthrough on the theories of milk fat depression emerged following a refocus on trans fatty acids and their association with milk fat percentage. The necessity for low fiber to induce altered rumen fermentation and low $\mathrm{pH}$, and a source of UFA to induce low milk fat syndrome was clearly demonstrated by Griinari et al. (1998). In presence of low rumen $\mathrm{pH}$ and UFA, about half of the C18:1 fatty acid in milk fat was trans-10 18:1. Although trans-10 18:1 is closely associated with milk fat depression (Loor et al., 2005), it is likely not the cause (Shingfield and Griinari, 2007). Bauman and colleagues (Baumgard et al., 2000) demonstrated severe milk fat depression in cows infused with trans-10, cis-12 CLA but no depression following infusion of the cis9,trans-11 CLA isomer. Thus, it was concluded that trans-10,cis-12 CLA is the most likely cause of milk fat depression, with infusion studies demonstrating the need for only a few grams of this CLA isomer to cause a marked decline in milk fat yield (Figure 5). The history of low milk fat syndrome is described in detail by Bauman and Griinari (2001), and the role of $\mathrm{BH}$ intermediates in milk fat depression is reviewed by Shingfield and Griinari (2007).

Further research explored nutritional risk factors for the formation of bioactive CLA that causes milk fat depression. These included the influences of amounts of UFA fed, type and amount of fiber, rumen $\mathrm{pH}$, ionophores, and rates of starch degradability. Formation of CLA in the rumen was also a function of feed management practices such as overcrowding at the bunk, inadequate feed mixing, frequency of feeding, and feed storage practices. All of these factors and their interactions continue to be investigated to determine the best practices for overcoming milk fat depression. In some cases, nutritionists have chosen to limit or even avoid supplementing diets with unsaturated fats rather than risk milk fat depression. Another approach by some is to take advantage of the benefits of unsaturated fat 
sources by following reasonable fat-feeding guidelines that limit the risk of milk fat depression.

\section{FEEDING SPECIFIC FATTY ACIDS IS EXPLORED}

As research continues on feeding traditional animaland plant-based fats, new interest in effects of feeding single fatty acids has occurred, extending beyond their energy contribution to include investigating potent structural, metabolic, and physiological effects of fatty acids, including the conversion of linoleic and linolenic acids to multiple eicosanoids (Palmquist, 2009).

Petit et al. (2002) examined the effects of feeding n-3 fatty acids from formaldehyde-treated linseed or duodenal infusions of linseed oil. Increased supply of n-3 fatty acid had effects on reproductive status, including larger CL as well as effects on prostaglandins that favored higher pregnancy rates. Since then, studies published on specific fatty acids are too numerous to detail. Some recent examples include linoleic and linolenic acid effects on oxylipid biosynthesis in mammary tissue and the severity of mastitis (Ryman et al., 2017), CLA and essential fatty acid effects on cellular response against oxidative damage (Basiricò et al., 2017), and altered ratio of n-3 and n-6 fatty acid effects on immune function and the inflammatory response in cows (Greco et al., 2015). With interest in feeding specific UFA to cows came questions about ruminal disappearance of docosahexaenoic acid and EPA (AbuGhazaleh and Jenkins, 2004a,b).

Interest in single fatty acids, however, was not confined only to UFA. Recently, other rumen-inert products containing $>85 \%$ palmitic acid have been studied intensively in terms of their effects to increase milk fat percentage. In an early study by Mosley et al. (2007), $0,500,1,000$, and $1,500 \mathrm{~g} / \mathrm{d}$ of an $87 \%$ palmitic acid product was fed; DMI, milk, fat and protein yields, and milk fat percent were increased by supplementing $500 \mathrm{~g} / \mathrm{d}$, without further increases at higher levels of supplementation. Lock et al. (2013) and Piantoni et al. (2013) both supplemented $2 \%$ palmitic-rich $(>86 \%)$ fats and reported results similar to those observed by Mosley et al. (2007); that is, increased milk and fat yields, with little or no effect on de novo synthesis of milk fatty acids. Diets supplemented with $>98 \%$ C18:0 at $2 \%$ of DM did not decrease de novo synthesis of milk fatty acids, but very little of the supplemental C18:0 was transferred to milk fat, in contrast to responses to C16:0 (Rico et al., 2014; Piantoni et al., 2015a). Similarly, when comparing C16 fat with calcium soaps of palm fatty acid distillate (Rico et al., 2014), the soap product decreased synthesis of de novo fatty acids by $7 \%$, related to low amounts of ruminally formed trans fatty acids, decreased C16:0 by $15 \%$, probably because of different intakes of this fatty acid, and increased C18 fatty acids by $10 \%$. The effect of feeding high C16 supplements on milk fat percent should not, perhaps, be surprising in light of early research by Kinsella and Gross (1973), who showed that palmitic acid stimulated glyceride synthesis in mammary tissue, and by Hansen and Knudsen (1987a,b), who reported that palmitic acid stimulated mammary synthesis of butyrate and incorporation of all de novo synthesized fatty acids into glycerides. Research by J. W. McFadden's group has provided new insights into mechanisms by which C16:0 influences fatty acid metabolism. In cows supplemented with 16:0, plasma concentrations of total ceramide and glucosylceramide (GlcCer) decreased as lactation advanced, and ceramide and GlcCer were elevated. Palmitic acid feeding increased hepatic ceramide levels, a response not observed in skeletal muscle tissue. Plasma ceramides were positively correlated with plasma nonesterified fatty acids and milk yield, and positively correlated with nonesterified fatty acid concentrations following a glucose challenge. The data demonstrated a remodeled plasma and hepatic sphingolipidome in midlactation dairy cows fed 16:0. The potential involvement in ceramide in homeorhetic nutrient partitioning to support lactation requires further consideration (Rico et al., 2016). They reported also that supplementing 16:0 increases plasma ceramides that induce insulin resistance and decease glucose-stimulated disappearance of fatty acids from plasma, concordant with increased milk and fat yield (Mathews et al., 2016).

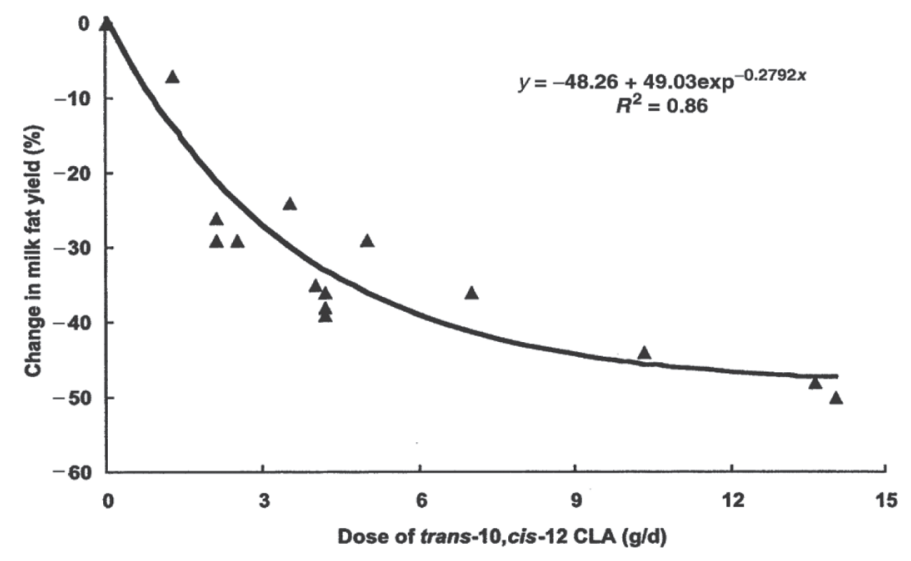

Figure 5. Results from de Veth et al. (2004), depicting potency of trans-10,cis-12 CLA isomer intestinally infused into lactating cows to decrease milk fat yield. Results of this study helped to establish the trans-10,cis-12 CLA isomer as the cause of milk fat depression, which has subsequently been labeled the "biohydrogenation theory." Used with permission of Lipids and American Oil Chemists' Society. 


\section{SUMMARY AND FUTURE DIRECTIONS}

Research on supplementing fats has progressed through several stages in the past century; from the early use of fats only to increase milk fat percent, to research by milk chemists on dietary fat effects on milk fat composition, and later to questions concerning the need for fat alter milk fat composition and for maximum milk yield. In the past $50 \mathrm{yr}$, development of research methods for physiology, nutrition, and metabolism, such as GLC, biochemistry, statistics, and modeling, have permitted more focused studies to define how the cow uses fat. Most important with respect to the role of fats has been the continuing increase in milk production potential, which has caused the cow to require ever-increasing amounts of energy for maximum milk yield. Supplemental fats are now used in almost all lactation rations, whether they be oilseeds or commercial ruminal inert fats; very little free oil or tallow is now used.

Fat is now included in all modern computerized models for formulating lactation rations. Supplemental fat will be required as herd milk production grows increasingly beyond $15,000 \mathrm{~kg} / \mathrm{yr}$. Formulations may be developed to use whole seeds for milk yield, SFA or calcium soaps for fat production, and calcium soaps, whole soybeans, and fish oil for reproduction.

For many years now, dairy research has focused on supplementing fats to "improve healthfulness" of the milk fatty acid profile or to increase "beneficial fatty acids" (Palmquist et al., 2006) by decreasing SFA and increasing the proportion of UFA. Such approaches may be useful, although many are faulty in many respects: "improve" is subjective, not objective, and most changes in fatty acid profile have been insignificant in terms of the role of milk fat in the total diet. Similarly, such terms as "improved ratio of polyunsaturated to saturated fatty acids (P/S ratio)" and "atherogenic index" are misleading because these terms apply only to total foods consumed, not individual ingredients, if they have any validity at all. Further, efforts to make milk fat "more healthful" detract from the superior qualities of milk as a food (Patton, 2004) and, increasingly, as a source of functional foods. Finally, recent research (German et al., 2009) showed that there is no clear evidence that dairy food consumption is consistently associated with a higher risk of cardiovascular disease. Siri-Tarino et al. (2010b), in a meta-analysis of prospective epidemiologic studies, found no significant evidence for concluding that dietary saturated fat is associated with an increased risk of cardiovascular heart disease or cardiovascular disease, and Siri-Tarino et al. (2010a) have shown that SFA improve the profile of small and large low density lipoprotein (LDL) particles compared with the effects of dietary carbohydrate. Later studies also support the conclusion that dairy fats are not the unhealthy food component that has been portrayed in some of the scientific, medical, and popular literature. Milk and milk components will continue to be subjects of research as sources of nutritional and functional foods, and we can hope that the concern for an association between milk SFA and health will decline.

\section{REFERENCES}

AbuGhazaleh, A. A., and T. C. Jenkins. 2004a. Disappearance of docosahexaenoic acid and eicosapentaenoic acids from cultures of mixed ruminal microorganisms. J. Dairy Sci. 87:645-651.

AbuGhazaleh, A. A., and T. C. Jenkins. 2004b. Short communication: Docosahexaenoic acid promotes vaccenic acid accumulation in mixed ruminal cultures when incubated with linoleic acid. J. Dairy Sci. 87:1047-1050.

Allen, M. S. 2014. Review. Drives and limits to feed intake in ruminants. Anim. Prod. Sci. 54:1513-1524. https://doi.org/10.1071/ AN14478.

Ashes, J. R., S. K. Gulati, and T. W. Scott. 1997. Symposium: New approaches to changing milk composition. Potential to alter the content and composition of milk fat through nutrition. J. Dairy Sci. 80:2204-2212.

Ashes, J. R., P. St. Vincent Welch, S. K. Gulati, T. W. Scott, and G. H. Brown. 1992. Manipulation of the fatty acid composition of milk by feeding protected canola seeds. J. Dairy Sci. 75:1090-1096.

Avila, C. D., E. J. DePeters, H. Perez-Monti, S. J. Taylor, and R. A. Zinn. 2000. Influences of saturation ratio of supplemental dietary fat on digestion and milk yield in dairy cows. J. Dairy Sci. 83:1505-1519.

Baldwin, R. L., N. E. Smith, J. Taylor, and M. Sharp. 1980. Manipulating metabolic parameters to improve growth rate and milk secretion. J. Anim. Sci. 51:1416-1428.

Banks, W., J. L. Clapperton, and M. E. Ferrie. 1976. Effect of feeding fat to dairy cows receiving a fat-deficient basal diet. II. Fatty acid composition of the milk fat. J. Dairy Res. 43:219-227.

Barletta, R. V., J. R. Gandra, V. P. Veterro, C. E. Araujo, T. A. Del Valle, G. F. del Almeida, E. F. deJesus, R. D. Mingoti, B. C. Benevento, J. E. de Freitas Jr., and F. P. Renno. 2016. Ruminal biohydrogenation and abomasal flow of fatty acids in lactating cows: Oilseeds provide ruminal protection for fatty acids. Anim. Feed Sci. Technol. 219:111-121.

Basiricò, L., P. Morera, D. Dipasquale, A. Tröscher, and U. Bernabucci. 2017. Comparison between conjugated linoleic acid and essential fatty acids in preventing oxidative stress in bovine mammary epithelial cells. J. Dairy Sci. 100:2299-2309.

Bateman, H. G., II, and T. C. Jenkins. 1998. Influence of soybean oil in high fiber diets fed to nonlactating cows on ruminal unsaturated fatty acids and nutrient digestibility. J. Dairy Sci. 81:2451-2458.

Bauman, D. E., R. E. Brown, and C. L. Davis. 1970. Pathways of fatty acid synthesis and reducing equivalent generation in mammary gland of rat, sow, and cow. Arch. Biochem. Biophys. 140:237-244.

Bauman, D. E., and J. M. Griinari. 2001. Review. Regulation and nutritional manipulation of milk fat: Low milk fat syndrome. Livest. Prod. Sci. 70:15-21.

Baumgard, L. H., B. A. Corl, D. A. Dwyer, A. Saebø, and D. E. Bauman. 2000. Identification of the conjugated linoleic acid isomer that inhibits milk fat synthesis. Am. J. Physiol. Regul. Integr. Comp. Physiol. 278:R179-R184.

Beltrán-Barrientos, L. M., A. Hernández-Mendoza, M. J. TorresLlanez, A. F. González-Córdova, and B. Vallejo-Córdoba. 2016. Invited review: Fermented milk as antihypertensive functional food. J. Dairy Sci. 99:4099-4110.

Benson, J. A., C. K. Reynolds, D. J. Humphries, S. M. Rutter, and D. E. Beever. 2001. Effects of abomasal infusion of long-chain fatty 
acids on intake, feeding behavior and milk production in dairy cows. J. Dairy Sci. 84:1182-1191.

Boerman, J. P., J. L. Firkins, N. R. St-Pierre, and A. L. Lock. 2015. Intestinal digestibility of long-chain fatty acids in lactating dairy cows: A meta-analysis and meta-regression. J. Dairy Sci. 98:88898903.

Brooks, C. C., G. B. Garner, C. W. Gehrke, M. E. Muhrer, and W. H. Pfander. 1956. The effect of added fat on the digestion of cellulose and protein by ovine rumen microorganisms. J. Anim. Sci. $13: 758-764$

Brown, J. B., and S. Sutton. 1931. The effect of feeding menhaden (fish) oil on the secretion of milk and the composition of butterfat in the dairy cow. J. Dairy Sci. 14:125-135.

Bruns, H. R., A. R. Hippen, K. F. Kalscheur, and D. J. Schingoethe. 2015. Inclusion of various amounts of steam-flaked soybeans in lactating dairy cattle diets. J. Dairy Sci. 98:7218-7225.

Cant, J. P., E. J. DePeters, and R. L. Baldwin. 1993a. Mammary amino acid utilization in dairy cows fed fat and its relationship to milk protein depression. J. Dairy Sci. 76:762-774.

Cant, J. P., E. J. DePeters, and R. L. Baldwin. 1993b. Mammary uptake of energy metabolites in dairy cows fed fat and its relationship to milk protein depression. J. Dairy Sci. 76:2254-2265.

Carroll, D. J., M. J. Jerred, R. R. Grummer, D. K. Combs, R. A. Pierson, and E. R. Hauser. 1990. Effects of fat supplementation and immature alfalfa to concentrate ratio on plasma progesterone, energy balance, and reproductive traits of dairy cattle. J. Dairy Sci. 73:2855-2863.

Chagas, L. M., J. J. Bass, D. Blache, C. R. Burke, J. K. Kay, D. R. Lindsay, M. C. Lucy, G. B. Martin, S. Meier, F. M. Rhodes, J. R. Roche, W. W. Thatcher, and R. Webb. 2007. Invited review: New perspectives on the roles of nutrition and metabolic priorities in the subfertility of high-producing dairy cows. J. Dairy Sci. 90:4022-4032.

Choi, B.-R., and D. L. Palmquist. 1996. High fat diets increase plasma cholecystokinin and pancreatic polypeptide, and decrease plasma insulin and feed intake in lactating cows. J. Nutr. 126:2913-2919.

Choi, B.-R., D. L. Palmquist, and M. S. Allen. 2000. Cholecystokinin mediates depression of feed intake in dairy cattle fed high fat diets. Domest. Anim. Endocrinol. 19:159-175.

Clare, D. A., and H. E. Swaisgood. 2000. Bioactive milk peptides: A prospectus. J. Dairy Sci. 83:1187-1195.

Cook, L. J., T. W. Scott, and Y. S. Pan. 1972. Formaldehyde-treated casein-safflower oil supplement for dairy cows. I. Effect on the fatty-acid composition of plasma and milk lipids. J. Dairy Res. 39:211-218.

Coppock, C. E., J. K. Lanham, and J. I. Horner. 1987. A review of the nutritive value and utilization of whole cottonseed, cottonseed meal and associated by-products by dairy cattle. Anim. Feed Sci. Technol. 18:89-129.

Davis, C. L., and R. E. Brown. 1970. Low-fat milk syndrome. Pages 545-565 in Physiology of Digestion and Metabolism in the Ruminant. A. T. Phillipson, ed. Oriel Press, Newcastle upon Tyne, UK.

Davison, K. L., and W. Woods. 1960. Influence of fatty acids upon digestibility of ration components by lambs and upon cellulose digestion in vitro. J. Anim. Sci. 19:54-59.

Dawson, R. M. C., and P. Kemp. 1970. Biohydrogenation of dietary fats in ruminants. Pages 504-518 in Physiology of Digestion and Metabolism in the Ruminant. A. T. Phillipson, ed. Oriel Press, Newcastle upon Tyne, UK.

de Veth, M. J., J. M. Griinari, A. M. Pfeiffer, and D. E. Bauman. 2004 Effect of CLA on milk fat synthesis in dairy cows: Comparison of inhibition by methyl esters and free fatty acids, and relationships among studies. Lipids 39:365-372.

DePeters, E. J., and J. P. Cant. 1992. Nutritional factors influencing the nitrogen composition of bovine milk: A review. J. Dairy Sci. 75:2043-2070

Doreau, M., F. LeGay, and D. Bauchart. 1991. Effect of source and level of supplemental fat on total and ruminal organic matter and nitrogen digestion in dairy cows. J. Dairy Sci. 74:2233-2242.

Drackley, J. K., T. H. Klusmeyer, A. M. Trusk, and J. H. Clark. 1992 Infusion of long-chain fatty acids varying in saturation and chain length into the abomasum of lactating dairy cows. J. Dairy Sci $75: 1517-1526$.

Drackley, J. K., T. R. Overton, G. Ortiz-Gonzalez, A. D. Beaulieu, D. M. Barbano, J. M. Lynch, and E. G. Perkins. 2007. Responses to increasing amounts of high-oleic sunflower fatty acids infused into the abomasum of lactating dairy cows. J. Dairy Sci. 90:5165-5175.

el-Hag, G. A., and T. B. Miller. 1972. Evaluation of whisky distillery by-products: Part 6 . The reduction in digestibility of malt distillers grains by fatty-acids and the interaction with calcium and other reversal agents. J. Sci. Food Agric. 23:247-258.

Faldet, M. A., and L. D. Satter. 1991. Feeding heat-treated full fat soybeans to cows in early lactation. J. Dairy Sci. 74:3047-3054.

Firkins, J. L., and M. L. Eastridge. 1994. Assessment of the effects of iodine value on fatty acid digestibility, feed intake, and milk production. J. Dairy Sci. 77:2357-2366.

Fouladi-Nashta, A. A., C. G. Gutierrez, J. G. Gong, P. C. Garnsworthy, and R. Webb. 2007. Impact of dietary fatty acids on oocyte quality and development in lactating dairy cows. Biol. Reprod. $77: 9-17$.

Gall, L. S., W. Burroughs, P. Gerlaugh, and B. H. Edgington. 1949a. Special methods for rumen bacterial studies in the field. J. Anim. Sci. 8:433-440.

Gall, L. S., W. Burroughs, P. Gerlaugh, and B. H. Edgington. 1949b. Rumen bacteria in cattle and sheep on practical farm rations. J. Anim. Sci. 8:441-449.

Gall, L. S., C. N. Stark, and J. K. Loosli. 1947. The isolation and preliminary study of some physiological characteristics of the predominating flora from the rumen of cattle and sheep. J. Dairy Sci. 30:891-899.

Garton, G. A. 1963. Review. The composition and biosynthesis of milk lipids. J. Lipid Res. 4:237-254.

German, J. B., R. A. Gibson, R. M. Krauss, P. Nestel, B. Lamarche, W. A. van Staveren, J. M. Steijns, L. C. P. G. M. de Groot, A. L. Lock, and F. Destaillats. 2009. Review. A reappraisal of the impact of dairy foods and milk fat on cardiovascular disease risk. Eur. J. Nutr. 48:191-203.

Glasser, F., P. Schmidely, D. Sauvant, and M. Doreau. 2008. Digestion of fatty acids in ruminants: A meta-analysis of flows and variation factors: 2. C18 fatty acids. Animal 2:691-704.

Greco, L. F., J. T. Neves Neto, A. Pedrico, R. A. Ferrazza, F. S. Lima, R. S. Bisinotto, N. Martinez, M. Garcia, E. S. Ribeiro, G. C Gomes, J. H. Shin, M. A. Ballou, W. W. Thatcher, C. R. Staples, and J. E. P. Santos. 2015. Effects of altering the ratio of dietary n- 6 to n-3 fatty acids on performance and inflammatory responses to a lipopolysaccharide challenge in lactating Holstein cows. J. Dairy Sci. 98:602-617.

Griinari, J. M., D. A. Dwyer, M. A. McGuire, D. E. Bauman, D. L. Palmquist, and K. V. V. Nurmela. 1998. Trans-Octadecenoic acids and milk fat depression in lactating dairy cows. J. Dairy Sci 81:1251-1261.

Grummer, R. R. 1988. Influence of prilled fat and calcium salt of palm oil fatty acids on ruminal fermentation and nutrient digestibility. J. Dairy Sci. 71:117-123.

Grummer, R. R. 1991. Effect of feed on the composition of milk fat. J. Dairy Sci. 74:3244-3257.

Grummer, R. R., and D. J. Carroll. 1991. Effects of dietary fat on metabolic disorders and reproductive performance of dairy cattle. J. Anim. Sci. 69:3838-3852.

Ha, Y. L., N. K. Grimm, and M. W. Pariza. 1987. Anticarcinogens from fried ground beef: Heat altered derivatives of linoleic acid Carcinogenesis 8:1881-1887.

Hansen, H. O., and J. Knudsen. 1987a. Effect of exogenous long-chain fatty acids on lipid biosynthesis in dispersed ruminant mammary gland epithelial cells: Esterification of long-chain exogenous fatty acids. J. Dairy Sci. 70:1344-1349.

Hansen, H. O., and J. Knudsen. 1987b. Effect of exogenous long-chain fatty acids on individual fatty acid synthesis by dispersed ruminant mammary gland cells. J. Dairy Sci. 70:1350-1354.

Harfoot, C. G. 1978. Anatomy, physiology and microbiology of the ruminant digestive tract. Prog. Lipid Res. 17:1-19. 
Harfoot, C. G., M. L. Crouchman, R. C. Noble, and J. H. Moore. 1974. Competition between food particles and rumen bacteria in the uptake of long-chain fatty acids and triglycerides. J. Appl. Bacteriol. 37:633-641.

Heinrichs, A. J., D. L. Palmquist, and H. R. Conrad. 1982. Feed intake patterns of cows fed high fat grain mixtures. J. Dairy Sci. 65:1325-1328.

Hellgren, L. I. 2010. Phytanic acid: An overlooked bioactive fatty acid in milk fat? Ann. N. Y. Acad. Sci. 1190:42-49.

Henry, W. A., and F. B. Morrison. 1916. Feeds and Feeding. 16th ed. The Lakeside Press, R. R. Donnelley \& Sons Co., Chicago, IL.

Hilditch, T. P. 1956. The Chemical Constitution of Natural Fats. 3rd ed. John Wiley \& Sons Inc., New York, NY.

Hurtaud, C., F. Faucon, S. Couvreur, and J.-L. Peyraud. 2010. Linear relationship between increasing amounts of extruded linseed in dairy cow diet and milk fatty acid composition and butter properties. J. Dairy Sci. 93:1429-1443.

James, A. T., and A. J. P. Martin. 1956. Gas-liquid chromatography: The separation and identification of methyl esters of saturated and unsaturated acids from formic acid to n-octadecanoic acid. Biochem. J. 63:144-152.

Jenkins, T. C., and W. C. Bridges Jr.. 2007. Protection of fatty acids against ruminal biohydrogenation in cattle. Eur. J. Lipid Sci. Technol. 109:778-789.

Jenkins, T. C., and K. J. Harvatine. 2014. Lipids feeding and milk fat depression. Vet. Clin. North Am. Food Anim. Pract. 30:623-642.

Jenkins, T. C., and M. A. McGuire. 2006. Major advances in nutrition: Impact on milk composition. J. Dairy Sci. 89:1302-1310.

Jenkins, T. C., and D. L. Palmquist. 1982. Effect of added fat and calcium on in vitro formation of insoluble fatty acid soaps and cell wall digestibility. J. Anim. Sci. 55:957-963.

Jenkins, T. C., and D. L. Palmquist. 1984. Effect of fatty acids or calcium soaps on rumen and total nutrient digestibility of dairy rations. J. Dairy Sci. 67:978-986.

Jensen, R. G. 2002. The composition of bovine milk lipids: January 1995 to December 2000. J. Dairy Sci. 85:295-350.

Jerred, M. J., D. J. Carroll, D. K. Combs, and R. R. Grummer. 1990. Effects of fat supplementation and immature alfalfa to concentrate ratio on lactation performance of dairy cattle. J. Dairy Sci. $73: 2842-2854$.

Kanekanian, A., ed. 2014. Milk and Dairy Products as Functional Foods. Wiley-Blackwell Ltd., Oxford, UK.

Katz, I., and M. Keeney. 1966. Characterization of the octadecenoic acids in rumen digesta and rumen bacteria. J. Dairy Sci. 49:962966.

Kepler, C. R., K. P. Hirons, J. J. McNeill, and S. B. Tove. 1966. Intermediates and products of the biohydrogenation of linoleic acid by Butyrivibrio fibrisolvens. J. Biol. Chem. 241:1350-1354.

Kinsella, J. E., and M. Gross. 1973. Palmitic acid and initiation of mammary glyceride synthesis via phosphatidic acid. Biochim. Biophys. Acta 316:109-113.

Kleppe, B. B., R. J. Aiello, R. R. Grummer, and L. E. Armentano. 1988. Triglyceride accumulation and very low density lipoprotein secretion by rat and goat hepatocytes in vitro. J. Dairy Sci. $71: 1813-1822$

Klusmeyer, T. H., and J. H. Clark. 1991. Effects of dietary fat and protein on fatty acid flow to the duodenum and in milk produced by dairy cows. J. Dairy Sci. 74:3055-3067.

Kronfeld, D. S. 1976. The potential importance of the proportions of glucogenic, lipogenic and aminogenic nutrients in regard to the health and productivity of dairy cows. Fortschr. Tierphysiol. Tierernahr. 7:3-26.

LaCount, D. W., J. K. Drackley, S. O. Laesch, and J. H. Clark. 1994 Secretion of oleic acid in milk fat in response to abomasal infusions of canola or high oleic sunflower fatty acids. J. Dairy Sci. $77: 1372-1385$

Litherland, N. B., S. Thire, A. D. Beaulieu, C. K. Reynolds, J. A. Benson, and J. K. Drackley. 2005. Dry matter intake is decreased more by abomasal infusion of unsaturated free fatty acids than by unsaturated triglycerides. J. Dairy Sci. 88:632-643.
Lock, A. L., C. L. Preseault, J. E. Rico, K. E. DeLand, and M. S. Allen. 2013. Feeding a C16:0-enriched fat supplement increased the yield of milk fat and improved conversion of feed to milk. J. Dairy Sci. 96:6650-6659.

Loor, J. J., A. Ferlay, A. Ollier, M. Doreau, and Y. Chilliard. 2005. Relationship among trans and conjugated fatty acids and bovine milk fat yield due to dietary concentrate and linseed oil. J. Dairy Sci. 88:726-740.

Loosli, J. K., L. A. Maynard, and H. L. Lucas. 1944. IV. Further studies of the influence of different levels of fat intake upon milk secretion. Page 3 in Cornell Univ. Agric. Exp. Sta. Memoir 265. Cornell University, Ithaca, NY.

Lough, A. K. 1970. Aspects of lipid digestion in the ruminant. In Physiology of Digestion and Metabolism in the Ruminant. A. T. Phillipson, ed. Oriel Press, Newcastle upon Tyne, UK.

Lucas, H. L., and J. K. Loosli. 1944. The effect of fat upon the digestion of nutrients by dairy cows. J. Anim. Sci. 3:3-11.

Lucy, M. C., C. R. Staples, F. M. Michel, W. W. Thatcher, and D. J. Bolt. 1991. Effect of feeding calcium soaps to early postpartum dairy cows on plasma progesterone $\mathrm{F}_{2 \alpha}$, luteinizing hormone, and follicular growth. J. Dairy Sci. 74:483-489.

Mathews, A. T., J. E. Rico, N. T. Sprenkle, A. L. Lock, and J. W. McFadden. 2016. Increasing palmitic acid intake enhances milk production and prevents glucose-stimulated fatty acid disappearance without modifying systemic glucose tolerance in mid-lactation dairy cows. J. Dairy Sci. 99:8802-8816.

Maynard, L. A. 1937. Animal Nutrition. 1st ed. McGraw-Hill, New York, NY

Maynard, L. A., J. K. Loosli and C. M. McCay. 1941. III. Further studies of the influence of different levels of fat intake upon milk secretion. Page 3 in Cornell Univ. Agric. Exp. Sta. Bull. 753. Cornell University, Ithaca, NY.

Maynard, L. A., C. M. McCay, and L. L. Madsen. 1936. The influence of food fat of varying degrees of unsaturation upon blood lipids and milk fat. J. Dairy Sci. 19:49-53.

McCandlish, A. C. 1921. The use of cottonseed meal to increase the percentage of fat in milk. J. Dairy Sci. 4:310-333.

McCay, C. M., and L. A. Maynard. 1935. The effect of ingested cod liver oil, shark liver oil, and salmon oil upon the composition of the blood and milk of lactating cows. J. Biol. Chem. 109:29-37.

McDonald, I. W., and T. W. Scott. 1977. Foods of ruminant origin with elevated content of polyunsaturated fatty acids. World Rev. Nutr. Diet. 26:144-207.

Mills, S., R. P. Ross, C. Hill, G. F. Fitzgerald, and C. Stanton. 2011 Milk intelligence: Mining milk for bioactive substances associated with human health. Int. Dairy J. 21:377-401.

Moallem, U., D. Vyas, B. B. Teter, P. Delmonte, M. Zachut, and R. A Erdman. 2012. Transfer rate of $\alpha$-linolenic acid from abomasally infused linseed oil into milk fat and the effects on milk fatty acid composition in dairy cows. J. Dairy Sci. 95:5276-5284.

Moate, P. J., W. Chalupa, T. C. Jenkins, and R. C. Boston. 2004. A model to describe ruminal metabolism and intestinal absorption of long chain fatty acids. Anim. Feed Sci. Technol. 112:79-105.

Moate, P. J., W. Chalupa, T. C. Jenkins, and R. C. Boston. 2008. A model to describe ruminal metabolism and intestinal absorption of long chain fatty acids. J. Dairy Sci. 91:1175-1188.

Monroe, C. F., and A. E. Perkins. 1939. A study of the $\mathrm{pH}$ values of the ingesta of the bovine rumen. J. Dairy Sci. 12:983-991.

Moore, L. A., G. T. Hoffman, and M. H. Berry. 1945. The effect of two different methods of feeding cod-liver oil on fat test in milk. J. Dairy Sci. 28:161-166.

Morales, M. S., D. L. Palmquist, and W. P. Weiss. 2000. Effects of fat source and copper on unsaturation of blood and milk triacylglycerol fatty acids in Holstein and Jersey cows. J. Dairy Sci. 83:2105-2111.

Mosley, S. A., E. E. Mosley, B. Hatch, J. I. Szasz, A. Corato, N. Zacharias, D. Howes, and M. A. McGuire. 2007. Effect of varying levels of fatty acids from palm oil on feed intake and milk production in Holstein cows. J. Dairy Sci. 90:987-993. 
Nevins, W. B., M. B. Alleman, and L. T. Peck. 1926. The effect of fat in the ration upon the percentage fat content of the milk. J. Dairy Sci. 9:307-345

Palmer, L. S., and D. P. Crockett. 1917. The composition and market qualities of butter when corn silage is fed with cottonseed meal. J. Dairy Sci. 1:235-245.

Palmquist, D. L. 1991. Influence of source and amount of dietary fat on digestibility in lactating cows. J. Dairy Sci. 74:1354-1360.

Palmquist, D. L. 1994. The role of dietary fats in efficiency of ruminants. J. Nutr. 124:1377S-1382S.

Palmquist, D. L. 2007. Biohydrogenation then and now. Eur. J. Lipid Sci. Technol. 109:737-739.

Palmquist, D. L. 2009. Omega-3 fatty acids in metabolism, health, and nutrition and for modified animal product foods. Prof. Anim. Sci. 25:207-249.

Palmquist, D. L., A. D. Beaulieu, and D. M. Barbano. 1993. ADSA Foundation Symposium: Milk fat synthesis and modification. Feed and animal factors influencing milk fat composition. J. Dairy Sci. $76: 1753-1771$.

Palmquist, D. L., and H. R. Conrad. 1971. Origin of plasma fatty acids in lactating cows fed high grain or high fat diets. J. Dairy Sci. 54:1025-1033

Palmquist, D. L., and H. R. Conrad. 1978. High fat rations for dairy cows. Effects on feed intake, milk and fat production, and plasma metabolites. J. Dairy Sci. 61:890-901.

Palmquist, D. L., and H. R. Conrad. 1980. High fat rations for dairy cows. Tallow and hydrolyzed blended fat at two intakes. J. Dairy Sci. 63:391-395

Palmquist, D. L., C. L. Davis, R. E. Brown, and D. S. Sachan. 1969 Availability and metabolism of various substrates in ruminants. V. Entry rate into the body and incorporation into milk fat of D (-) 3-hydroxybutyrate. J. Dairy Sci. 52:633-638.

Palmquist, D. L., and T. C. Jenkins. 1980. Fat in lactation rations. J. Dairy Sci. 63:1-14. (Review)

Palmquist, D. L., and T. C. Jenkins. 1982. Calcium soaps as a fat supplement in dairy cattle feeding. Pages 477-481 in Proc. XII World Congress of Diseases of Cattle, Amsterdam, the Netherlands.

Palmquist, D. L., and T. C. Jenkins. 2003. Challenges with fats and fatty acid methods. J. Anim. Sci. 81:3250-3254.

Palmquist, D. L., and W. Mattos. 1978. Turnover of lipoproteins and transfer to milk fat of dietary (1-carbon-14) linoleic acid in lactating cows. J. Dairy Sci. 61:561-565.

Palmquist, D. L., K. Stelwagen, and P. H. Robinson. 2006. Preface: Modifying milk composition to increase use of dairy products in healthy diets. Anim. Feed Sci. Technol. 131:149-153.

Pariza, M. W. 1999. The biological activities of conjugated linoleic acid. Pages 12-20 in Advances in Conjugated Linoleic Acid Research. Vol. 1. M. P. Yurawecz, M. M. Mossoba, J. K. G. Kramer, M. W. Pariza, and G. J. Nelson, ed. AOCS Press, Champaign, IL.

Parodi, P. W. 1977. Conjugated octadecanoic acids of milk fat. J. Dairy Sci. 60:1550-1553.

Parodi, P. W. 1994. Conjugated linoleic acid-An anticarcinogenic fatty acid present in milk fat. Aust. J. Dairy Technol. 49:93-97.

Patton, S. 2004. Milk: Its remarkable contribution to human health and well-being. Transaction Publishers, New Brunswick, NJ.

Patton, S., R. D. McCarthy, L. Evans, and T. R. Lynn. 1960. Structure and synthesis of milk fat. I. Gas chromatographic analysis. J. Dairy Sci. 43:1187-1195

Petit, H. V., R. J. Dewhurst, N. D. Scollan, J. G. Proulx, M. Khalid, W. Haresign, H. Twagiramungu, and G. E. Mann. 2002. Milk production and composition, ovarian function, and prostaglandin secretion of dairy cows fed omega-3 fats. J. Dairy Sci. 85:889-899.

Piantoni, P., A. L. Lock, and M. S. Allen. 2013. Palmitic acid increased yields of milk and milk fat and nutrient digestibility across production level of lactating cows. J. Dairy Sci. 96:7143-7154.

Piantoni, P., A. L. Lock, and M. S. Allen. 2015a. Saturated fat supplementation interacts with dietary forage neutral detergent fiber content during the immediate postpartum and carryover periods in Holstein cows: Production responses and digestibility of nutrients. J. Dairy Sci. 98:3309-3322.
Piantoni, P., A. L. Lock, and M. S. Allen. 2015b. Saturated fat supplementation interacts with dietary forage neutral detergent fiber content during the immediate postpartum period in Holstein cows: Energy balance and metabolism. J. Dairy Sci. 98:3323-3334.

Piantoni, P., C. M. Ylioja, and M. S. Allen. 2015c. Feed intake is related to changes in plasma nonesterified fatty acid concentration and hepatic acetyl CoA content following feeding in lactating dairy cows. J. Dairy Sci. 98:6839-6847.

Pullen, D. L., J. S. Liesman, and R. S. Emery. 1990. A species comparison of liver slice synthesis and secretion of triacylglycerol from nonesterified fatty acids in media. J. Anim. Sci. 68:1395-1399.

Pullen, D. L., D. L. Palmquist, and R. S. Emery. 1989. Effect of days of lactation and methionine hydroxy analog on incorporation of plasma fatty acids into plasma triglycerides. J. Dairy Sci. 72:49-58.

Rabiee, A. R., K. Breinhild, W. Scott, H. M. Golder, E. Block, and I. J. Lean. 2012. Effect of fat additions to diets of dairy cattle on milk production and components: A meta-analysis and metaregression. J. Dairy Sci. 95:3225-3247.

Reid, J. T. 1956. Nutrition and feeding of dairy cattle. J. Dairy Sci. 39:735-763.

Reiser, R. 1951. Hydrogenation of polyunsaturated fatty acids by the ruminant. Fed. Proc. 10:236.

Rico, D. E., Y. Ying, and K. J. Harvatine. 2014. Comparison of enriched palmitic acid and calcium salts of palm fatty acids distillate fat supplements on milk production and metabolic profiles of highproducing dairy cows. J. Dairy Sci. 97:5637-5644.

Rico, J. E., A. T. Mathews, J. Lovett, N. J. Haughey, and J. W. McFadden. 2016. Palmitic acid feeding increases ceramide supply in association with increased milk yield, circulating nonesterified fatty acids, and adipose tissue responsiveness to a glucose challenge. J. Dairy Sci. 99:8817-8830.

Ruegsegger, G. J., and L. H. Schultz. 1985. Response of high producing dairy cows in early lactation to the feeding of heat-treated whole soybeans. J. Dairy Sci. 68:3272-3279.

Ryman, V. E., N. Packiriswamy, B. Norby, S. E. Schmidt, A. L. Lock, and L. M. Sordillo. 2017. Supplementation of linoleic acid (C18: $2 \mathrm{n}-6)$ or $\alpha$-linolenic acid (C18:3n-3) changes microbial agonist-induced oxylipid biosynthesis. J. Dairy Sci. 100:1870-1887.

Schingoethe, D. J., and D. P. Casper. 1991. Total lactational response to added fat during early lactation. J. Dairy Sci. 74:2617-2622.

Schneider, P. L., D. Sklan, D. S. Kronfeld, and W. Chalupa. 1990. Responses of dairy cows in early lactation to bovine somatotropin and ruminally inert fat. J. Dairy Sci. 73:1263-1268.

Scott, T. W., L. J. Cook, and S. C. Mills. 1971. Protection of dietary polyunsaturated fatty acids against microbial hydrogenation in ruminants. J. Am. Oil Chem. Soc. 48:358-364.

Shaw, J. C., and W. E. Ensor. 1959. Effect of feeding cod liver oil and unsaturated fatty acids on rumen volatile fatty acids and milk fat content. J. Dairy Sci. 42:1238-1240.

Shingfield, K. J., and J. M. Griinari. 2007. Role of biohydrogenation intermediates in milk fat depression. Eur. J. Lipid Sci. Technol. 109:799-816.

Shorland, F. B., R. O. Weenink, A. J. Johns, and I. R. C. McDonald. 1957. The effect of sheep rumen contents on unsaturated fatty acids. Biochem. J. 67:328-333.

Silvestre, F. T., T. S. M. Carvalho, N. Francisco, J. E. P. Santos, C. R. Staples, T. C. Jenkins, and W. W. Thatcher. 2011. Effects of differential supplementation of fatty acids during the peripartum and breeding periods of Holstein cows: I. Uterine and metabolic responses, reproduction, and lactation. J. Dairy Sci. 94:189-204.

Siri-Tarino, P. W., Q. Sun, F. B. Hu, and R. M. Krauss. 2010a. Saturated fat, carbohydrate, and cardiovascular disease. Am. J. Clin. Nutr. 91:502-509

Siri-Tarino, P. W., Q. Sun, F. B. Hu, and R. M. Krauss. 2010b. Metaanalysis of prospective cohort studies evaluating the association of saturated fat with cardiovascular disease. Am. J. Clin. Nutr. 91:535-546.

Sklan, D., and P. Budowski. 1974. Desaturation and saturation of fatty acids by sheep rumen bacteria: optimal conditions and cofactor requirements. J. Dairy Sci. 57:56-60. 
Smith, L. M. 1961. Quantitative fatty acid analysis of milk fat by gasliquid chromatography. J. Dairy Sci. 44:607-622.

Smith, L. M., N. K. Freeman, and E. L. Jack. 1954. The unsaturated fatty acids of milk fat. III. Geometrical isomerism. J. Dairy Sci. 37:399-406.

Smith, L. M., and E. L. Jack. 1954a. The unsaturated fatty acids of milk fat I. Methyl ester fractionation and isolation of monoethenoid constituents. J. Dairy Sci. 37:380-389

Smith, L. M., and E. L. Jack. 1954b. The unsaturated fatty acids of milk fat. II. Conjugated and nonconjugated constituents. J. Dairy Sci. 37:390-398.

Staples, C. R., J. M. Burke, and W. W. Thatcher. 1998. Influence of supplemental fats on reproductive tissues and performance of lactating cows. J. Dairy Sci. 81:856-871.

Steele, W., R. C. Noble, and J. H. Moore. 1971. The effects of 2 methods of incorporating soybean oil into the diet on milk yield and composition in the cow. J. Dairy Res. 38:43-48.

Stocks, S. E., and M. S. Allen. 2012. Hypophagic effects of propionate increase with elevated hepatic acetyl coenzyme A concentration for cows in the early postpartum period. J. Dairy Sci. 95:3259-3268.

Stocks, S. E., and M. S. Allen. 2014. Effects of lipid and propionic acid infusions on feed intake of lactating dairy cows. J. Dairy Sci. 97:2297-2304.

Stoffel, C. M., P. M. Crump, and L. E. Armentano. 2015. Effect of dietary fatty acid supplements, varying in fatty acid composition, on milk fat secretion in dairy cattle fed diets supplemented to less than 3\% total fatty acids. J. Dairy Sci. 98:431-442.

Storry, J. E. 1970. Reviews of the progress of dairy science. Section A. Physiology. Ruminant metabolism in relation to the synthesis and secretion of milk fat. J. Dairy Res. 37:139-164.

Sutton, T. S., J. B. Brown, and E. W. Johnston. 1932. The effect of corn oil on milk and butterfat production and on the composition of butterfat in the dairy cow. J. Dairy Sci. 15:209-211.

Swift, R. W., J. W. Bratzler, W. H. James, A. D. Tillman, and D. C. Meek. 1948. The effect of dietary fat on utilization of the energy and protein of rations by sheep. J. Anim. Sci. 7:475-485.

Swift, R. W., E. J. Thacker, A. Black, J. W. Bratzler, and W. H. James. 1947. Digestibility of rations for ruminants as affected by proportions of nutrients. J. Anim. Sci. 6:432-444.

Thatcher, W. W., T. R. Bilby, J. A. Bartolome, F. Silvestre, C. R. Staples, and J. E. P. Santos. 2006. Strategies for improving fertility in the modern dairy cow. Theriogenology 65:30-44.

Tice, E. M., M. L. Eastridge, and J. L. Firkins. 1993. Raw soybeans and roasted soybeans of different particle sizes. 1. Digestibility and utilization by lactating cows. J. Dairy Sci. 76:224-235.
Tice, E. M., M. L. Eastridge, and J. L. Firkins. 1994. Raw soybeans and roasted soybeans of different particle sizes. 2. Fatty acid utilization by lactating cows. J. Dairy Sci. 77:166-180.

Tillman, A. D., and J. R. Brethour. 1958. The effect of corn oil upon the metabolism of calcium and phosphorus by sheep. J. Anim. Sci. 17:782-786.

Timmons, J. S., W. P. Weiss, D. L. Palmquist, and W. J. Harper 2001. Relationships among dietary roasted soybeans, milk components, and spontaneous oxidized flavor of milk. J. Dairy Sci. 84:2440-2449

Van Soest, P. J. 1963. Ruminant fat metabolism with particular reference to factors affecting low milk fat and feed efficiency: A review. J. Dairy Sci. 46:204-216.

Visioli, F., and A. Strata. 2014. Milk, dairy products, and their functional effects in humans: A narrative review of recent evidence. Adv. Nutr. 5:131-143.

Ward, G. M., and J. T. Reid. 1948. Mineral metabolism studies in dairy cattle: II. Effect of calcium and manganese and other trace elements on the metabolism of lipids during early lactation. J. Nutr. 35:249-255.

Wathes, D. C., D. R. E. Abayasekara, and R. J. Aitken. 2007. Polyunsaturated fatty acids in male and female reproduction. Biol Reprod. 77:190-201.

Weiss, W. P., and J. M. Pinos-Rodriguez. 2009. Production responses of dairy cows when fed supplemental fat in low- and high-forage diets. J. Dairy Sci. 92:6144-6155.

White, T. W., R. B. Grainger, F. H. Baker, and J. W. Stroud. 1958. Effect of supplemental fat on digestion and the ruminal calcium requirement of sheep. J. Anim. Sci. 17:797-803.

Wood, A. H. 1894. Effect of food on milk. Feeding with fats. Univ. New Hampshire Agric. Expt. Sta. Bull. 20. March. University of New Hampshire, Durham

Wood, F. W., M. F. Murphy, and W. L. Dunkley. 1974. Influence of elevated polyunsaturated fatty acids on processing and physical properties of butter. J. Dairy Sci. 58:839-845.

Woodward, T. E. 1923. Factors influencing percentage of fat in milk. J. Dairy Sci. 5:466-478.

Wu, Z., O. A. Ohajuruka, and D. L. Palmquist. 1991. Ruminal synthesis, biohydrogenation, and digestibility of fatty acids by dairy cows. J. Dairy Sci. 74:3025-3034.

\section{APPENDIX}

Table A1. Significant events in 100 years of fat feeding

\begin{tabular}{|l|l|l|}
\hline Date & Milestone & Reference \\
\hline 1929 & $\begin{array}{l}\text { Detailed studies of dietary fat effects on milk and fat production are initiated } \\
\text { at Cornell University (Ithaca, NY). }\end{array}$ & $\begin{array}{l}\text { Maynard et al., 1941; Loosli et al., } \\
1944\end{array}$ \\
\hline 1939 & $\begin{array}{l}\text { The use of rumen-fistulated cows enhances rumen fermentation studies } \\
\text { with fats. }\end{array}$ & Monroe and Perkins, 1939 \\
\hline 1949 & $\begin{array}{l}\text { Interactions of divalent minerals with fatty acids are investigated, and fecal } \\
\text { soaps are documented. }\end{array}$ & Ward and Reid, 1948 \\
\hline 1950 & Tallow and vegetable soapstocks become readily available as livestock feeds. & Brooks et al., 1956 \\
\hline
\end{tabular}


Table A1 (Continued). Significant events in 100 years of fat feeding

\begin{tabular}{|c|c|c|}
\hline Date & Milestone & Reference \\
\hline 1951 & Biohydrogenation is demonstrated in sheep rumen contents. & Reiser, 1951; Shorland et al., 1957 \\
\hline 1956 & $\begin{array}{l}\text { Biohydrogenation of unsaturated fatty acids yields stearic acid, trans mo- } \\
\text { nenes, and conjugated C18 fatty acids. }\end{array}$ & $\begin{array}{l}\text { Dawson and Kemp, 1970; Harf- } \\
\text { oot, } 1978\end{array}$ \\
\hline 1959 & $\begin{array}{l}\text { Unsaturated fatty acids are shown to reduce rumen fiber digestion and } \\
\text { acetate:propionate ratio. }\end{array}$ & Brooks et al., 1956 \\
\hline $1960 \mathrm{~s}$ & $\begin{array}{l}\text { Rumen microbiological studies are conducted that include fiber digestion } \\
\text { and biohydrogenation. }\end{array}$ & $\begin{array}{l}\text { Davison and Woods, 1960; El Hag } \\
\text { and Miller, } 1972\end{array}$ \\
\hline 1972 & $\begin{array}{l}\text { Encapsulated fats are developed in Australia to increase unsaturated fatty } \\
\text { acids in milk. }\end{array}$ & Scott et al., 1971 \\
\hline 1978 & $\begin{array}{l}\text { Approximately half of } \mathrm{C} 18 \text { fatty acids consumed are transferred directly to } \\
\text { milk. }\end{array}$ & Palmquist and Mattos, 1978 \\
\hline 1982 & $\begin{array}{l}\text { Supplemental fats change feeding patterns, including smaller, more frequent } \\
\text { meals and possibly reduced DMI. }\end{array}$ & Heinrichs et al., 1982 \\
\hline 1983 & $\begin{array}{l}\text { Preformed calcium salts of fatty acids are fed to cows, marking the begin- } \\
\text { ning of the "bypass fats" era. }\end{array}$ & Jenkins and Palmquist, 1984 \\
\hline 1990 & $\begin{array}{l}\text { Recommendations are made to limit total fat fed to equal the amount of } \\
\text { milk fat produced. }\end{array}$ & \\
\hline 1991 & $\begin{array}{l}\text { Fat supplements are shown to increase plasma progesterone and the num- } \\
\text { ber of large follicles in cows. }\end{array}$ & Lucy et al., 1991 \\
\hline 1998 & $\begin{array}{l}\text { Specific CLA isomers from rumen are established as the cause of milk fat } \\
\text { depression. }\end{array}$ & Griinari et al., 1998 \\
\hline 2001 & The biohydrogenation theory of milk fat depression is developed. & Bauman and Griinari, 2001 \\
\hline 2002 & $\begin{array}{l}\text { Over } 400 \text { fatty acids are reported in milk; most are products of biohydroge- } \\
\text { nation. }\end{array}$ & Jensen, 2002 \\
\hline 2007 & High palmitic fats are examined for their benefits on milk fat yield. & $\begin{array}{l}\text { Mosley et al., 2007; Lock et al., } \\
\text { 2013; Mathews et al., } 2016\end{array}$ \\
\hline 2010 & $\begin{array}{l}\text { Clear evidence indicates that saturated animal fats do not increase cardio- } \\
\text { vascular disease. }\end{array}$ & $\begin{array}{l}\text { German et al., 2009; Siri-Tarino et } \\
\text { al., 2010a, b }\end{array}$ \\
\hline 2015 & $\begin{array}{l}\text { Increasing the ratio of } n-3 \text { to } n-6 \text { fatty acids increases immune function in } \\
\text { dairy cows. }\end{array}$ & $\begin{array}{l}\text { Greco et al., 2015; Ryman et al., } \\
2017\end{array}$ \\
\hline
\end{tabular}

